\title{
The impact of payments for environmental services on communal lands: An analysis of the factors driving household land-use behavior in Ecuador
}

\begin{abstract}
This article examines how Payments for Environmental Services (PES) influence household land-use behavior in the context of common-property lands. PES programs have been increasingly applied to communities who collectively manage their lands. While a number of authors have expressed concerns about the ability of said programs to generate additional environmental benefits and the potential for PES to counter community resource management arrangements, few empirical studies have explicitly examined PES in the context of communal resource management. Here, we take advantage of the gradual rollout of an Ecuadorian PES program to compare land-use behavior on collective lands in participant communities to households in communities that are waiting to participate. The goals of the analysis are to (a) identify if the PES program has produced changes in land-use, (b) assess the degree to which household characteristics and communal governance conditions drive land-use behavior, and (c) explore the interplay between PES and communal resource management institutions. Data was gathered from a cross-sectional survey of 399 households located in 11 communities. We use difference-in-differences to estimate the average effect of PES program participation on household behavior. Logit models, coupled with qualitative analysis, unpack how communal governance characteristics influence land-use behavior and the interplay between communal governance conditions and PES. We find that PES reduced the number of households grazing collective lands by $12 \%$, however, household and communal governance factors are also instrumental in determining land-use decisions. Our results provide empirical insights into the debate over PES in collective resource management and
\end{abstract}


illustrate how PES and communal resource management institutions can build upon each other to attain desired household conservation behavior.

Keywords: Collective action; Conservation; Common-pool resource; Ecosystem services; Latin America;

Páramo 


\section{Introduction}

In the fields of conservation and international development, scholars have repeatedly called for diagnostic tools and associated theories to assess not only whether, but under what conditions, a specific policy tool works (Basurto \& Ostrom, 2009; Deaton, 2010; Miteva, Pattanayak, \& Ferraro, 2012; Ostrom, 2007). This article contributes to our understanding of if and how Payment for Environmental Services (PES) works in the context of collective resource management.

PES and related incentive-based conservation programs are quickly becoming the policy tool of choice to promote conservation in developing countries (Adhikari and Agrawal, 2013; Muradian et al., 2010; Wunder et al., 2008). PES programs are supported by major conservation organizations and international donors, and are the core of many countries' plans to achieve Reduced Emissions from Forest Degradation and Deforestation (REDD+) goals (Engel et al., 2008; Ferraro, 2011; WertzKanounnikoff \& Kongphan-Apirak, 2009). The conventional PES model is frequently defined as a voluntarily transaction in which a buyer agrees to pay a resource user to provide an environmental service, on the condition that the resource user provides said service (or land uses likely to secure such environmental service) (Ferraro \& Kiss, 2002; Wunder, 2005). In practice, however, PES programs include an array of incentive-based arrangements that vary with respect to the buyers and sellers, the incentive provided, and the degree of conditionality (Goldman-Benner et al., 2012; Muradian et al., 2010).

Proponents of PES argue that said programs may be a more just and effective means to achieve conservation outcomes as participants voluntarily enter a payment program and are compensated for providing the desired environmental services, or land-use proxies (Engel, et al., 2008; P. Ferraro \& Kiss, 2002; Wunder, 2005, 2013). There is, however, considerable debate over whether economic incentives are an appropriate tool for conservation. Particularly in in the context of resource-dependent 
communities, scholars express concerns about the social impacts of PES, and its effectiveness at attaining behavioral change and the desired environmental services (Igoe \& Brockington 2007; Livermann 2004; McAfee \& Shapiro 2010; Naeem et al. 2015; Pattanayak et al. 2010).

In recent years, governmental and non-governmental organizations have increasingly applied PES to communal systems where resource users share rights (de facto or de jure) to use and manage their common-pool resource systems (Dougill, et al., 2012; Kerr et al., 2014; Sommerville et al., 2010). In the communal context, a community agrees to participate in a PES arrangement and receive a collective payment for household compliance with the contract conditions (Kerr, et al., 2014). The application of payment programs to collectively managed resources obfuscates the relationship between the contract, payment and the individual resource use decisions found in more conventional individual PES agreements and raise a number of issues regarding the decision to participate, the ability of communities to transmit PES resource-use restrictions to all households, and equity implications (Kerr et al., 2014; Pascual et al. 2010; Sommerville et al., 2010).

Here, we address one piece of this discussion by considering how PES influences behavioral change on collectively managed lands. Previous research on the effectiveness of PES in providing additional conservation benefits has largely focused on the ability of payment programs to, on average, reduce deforestation levels, with a few studies looking specifically at behavioral change for a broader range of resource uses (Alix-Garcia et al., 2012; Arriagada et al., 2009, 2012; Bremer et al. 2014; Clements \& Milner-Gulland, 2015; Rico García-Amado et al., 2011; Sommerville, et al., 2010). While the findings are mixed, a number of studies point to the ability of PES to reduce deforestation (Alix-Garcia et al., 2012, Arriagada et al., 2009, 2012; Clements and Milner-Gulland, 2015), others find varying reductions in resource-use behavior (Bremer et al. 2014; Clements et al. 2015; Sommerville et al. 2010). Study findings suggest that there is substantial heterogeity across the impacts and point to the need to 
better understand the conditions associated with greater program effectiveness (Alix-Garcia et al., 2012; Boerner et al. 2016; Pattanayak et al., 2010).

With respect to the effectiveness of PES on collectively managed resource systems, of particular interest is how a community's governance characteristics may influence its ability to convey the PES land-use restrictions to all users (Clements et al., 2010; Hayes et al., 2015; Kerr et al., 2014; Sommerville et al., 2010), and how PES impacts may vary across households faced with different incentive structures (Kerr, et al. 2014; Kosoy et al. 2008). To our knowledge, no quantitative study on PES has analyzed the governance characteristics of the respective communities to assess how these characteristics, in addition to household characteristics, engage with PES to influence changes in land-use behaviors.

In this study, we examine the impacts of an Ecuadorian payment for conservation program on household land-use behavior on communal lands. The goals of the analysis are to assess whether, on average, the Ecuadorian payment program influences household land-use behavior to produce changes in land-use that would otherwise not have occurred absent the program, and to identify how communal governance characteristics mediate household land-use behavior and engage with PES.

Our analysis uses the "Institutional Analysis and Development" (IAD) framework developed by Ostrom and colleagues (Ostrom, 1990, 2005) to structure the various theories and associated variables predicted to influence rural land-use decisions and collective resource management. Cases were selected based on a quasi-experimental design that matched participant communities with nonparticipant communities. To address possible self-selection bias into the program, we compare land-use behavior in participant communities to households in communities that have expressed an interest in participating and are on an informal waitlist to participate. Data was gathered from a cross-sectional survey of 399 households located in 11 communities. Behavioral change is based on stated changes in land-use, which we further verify with field-based land-use assessments and key informant interviews. 
We use difference-in-differences to estimate the average effect of PES program participation on household behavior. Logit models, coupled with qualitative analysis unpack how communal governance characteristics influence land-use behavior and the interplay between communal governance conditions and PES.

We find that, on average, the Ecuadorian payment program significantly reduces household use of collective lands, namely via a decrease in the number of households grazing. However, household and communal governance factors also shape land-use decisions. Furthermore, our findings suggest that the Ecuadorian program performs better in communities with a history of land-use rules. Future research is needed to track behavioral change, institutional development, and actual changes in the provision of ecosystem services in the respective communities over time.

\section{Theoretical approach}

In the PES model, farmers are assumed to make land-use decisions that optimize their net financial benefits in light of perceived risks (Fisher, 2012; Wunder, 2013). While a substantial body of literature in land-economics supports the theory that farmers consider the expected benefits and costs in their resource-use decisions (Koontz, 2001; Mercer, 2004), interdisciplinary work in the social and behavioral sciences suggest that resource-use decisions are not purely economic. Nonmonetary and cognitive factors such as the noneconomic value that a farmer places on the resource, the perceived legitimacy of the prescribed land-uses and the communal norms associated with those uses may all shape behavior (Beedell \& Rehman, 2000; Chowdhury \& Turner, 2006; Grothmann \& Patt, 2005; Hirsch, et al., 2011; Koontz, 2001; Petheram \& Campbell, 2010; Vignola et al., 2010).

Furthermore, in the context of collective resource management, theoretical and empirical work suggests that household resource-use decisions depend on the community, and the respective 
governance institutions, in which the household resides (Agrawal, 2007; Ostrom, 1990; Ostrom et al., 1994). Researchers have consistently found a positive association between a community's governance characteristics and household resource use practices. Specifically, communities that are able to selforganize to address collective action problems, devise communal resource management rules, and monitor and enforce those rules are more likely to sustain their resource systems (Berkes \& Folke, 1998; Chhatre \& Agrawal, 2008; Coleman \& Steed, 2009; Gibson et al., 2005; Ostrom, 1990; Ostrom \& Nagendra, 2006; Persha et al., 2011).

While a number of PES scholars have discussed the potential role for communal organization and governance institutions in PES (Adhikari \& Agrawal, 2013; Clements, et al., 2010; Dougill, et al., 2012; Kosoy et al., 2008; Sommerville, et al., 2010), the ways in which PES programs interact with communal resource management systems are poorly understood (Dougill, et al., 2012; Kerr, et al., 2014; Muradian, 2013; Narloch et al., 2012). Some scholars have expressed concerns that economic incentives may crowd-out collective action to craft and monitor resource management rules and intrinsic motivations to produce the desired behavior (Agrawal et al., 2015; Cardenas et al., 2000; Kerr, et al., 2014; Narloch, et al., 2012; Vatn, 2010; Vollan, 2008). Others, however, contend that strong communal governance institutions may be critical to the success of PES initiatives on collective lands (Clements, et al., 2010; Dougill, et al., 2012; Kosoy, et al., 2008); and furthermore, that PES has the potential to empower and support a community's collective resource management capacities (Bremer et al., 2014; Clements, et al., 2010; Hayes et al., 2015; Muradian, 2013).

In this analysis, we use the IAD framework to incorporate the complex set of factors predicted to shape land-use decisions. In the IAD framework, actors are hypothesized to make decisions given the control they perceive to have over that decision, the information they have regarding their choice 
options, the likely outcomes, and the benefits and costs they perceive for these outcomes (Ostrom, 2009). Actors' decisions, however, are not made in a vacuum, but rather are influenced by the biophysical features of the resource, the community attributes corresponding to the specific actor, and the specific institutions aimed at shaping resource use (Ostrom, 2005). The IAD framework enables us to structure a more holistic analysis to understand the impact of PES participation, taking into account how house household attributes in conjunction with communal and biophysical factors may influence resource use in collective management settings such as those found in the Ecuadorian Andes.

\section{Context and case studies}

\subsection{Ecuador's Socio Bosque payment program}

In 2008, the Ecuadorian government created Programa Socio Bosque (PSB) with the dual goals of preventing the destruction and degradation of native ecosystems, and increasing income and human capital in the poorest communities of Ecuador (De Koning, et al., 2011). The program specifically targets ecosystems that are threatened, provide valuable environmental services such as regulation of hydrological systems, carbon storage, and biodiversity; and are located in the poorest regions (MAE, 2009).

Similar to many PES projects in the developing tropics, in PSB, the government provides an economic incentive to poor farmers and communities who voluntarily enter into conservation contracts in which they agree to conserve native ecosystems in return for direct payments depending on the number of hectares conserved. ${ }^{1}$ The program is not directly linked to a market and the payments are intended to act as an incentive or compensation for conservation behaviors; the payments are not

\footnotetext{
${ }^{1}$ It is important to note that the Ecuadorian government does not recognize Programa Socio Bosque as a PES program, however, the conditions coincide with what is generally considered PES.
} 
based on calculated opportunity costs (De Koning, et al., 2011). The program works with both individuals and communities, however, $88 \%$ of the conservation lands are under community contracts (MAE, 2012).

This study focuses specifically on PSB's efforts to conserve Ecuador's highland ecosystems, namely páramo lands. In South America, páramo, a high-elevation ecosystem of grasslands and shrubs (at about $3200 \mathrm{~m}$ ), houses valuable biodiversity and provides critical ecosystem services, including water provision and carbon storage in the soils (Buytaert \& De Bièvre, 2012; Farley et al., 2004; Farley et al., 2011; Madriñan et al., 2013). Páramo is native to the Andean mountain range that runs north-south through the center of Ecuador and provides water to many Andean countries' growing highland cities (Buytaert \& De Bièvre, 2012). In Ecuador, over 3 million people directly benefit from the páramo's water supply (Crespo, et al., 2010).

As in much of the northern Andes, in Ecuador, the páramo is threatened by subsistence land-use activities, urbanization and climate change. Although their respective impacts are poorly understood, farming, grazing and burning, in addition to afforestation with non-native species, are often considered to be principal threats that may degrade and destroy the páramo and its water storage capacity (Buytaert, et al., 2006; Crespo, et al., 2010; Farley et al. 2013; Hofstede, et al., 2014; Keating 2007; Madriñan, et al., 2013; Podwojewski et al., 2002). Research suggests that agriculture and intensive grazing can reduce the number of plant species, increase soil erosion, and reduce the ability of soils to regulate water (Buytaert et al. 2006; Podwojewski et al., 2002). We have, however, limited information on the carrying capacity of páramos and the impact of more extensive grazing practices (Hofstede, 1995; Hofstede et al., 2014). Likewise, burning, usually used to promote the growth of new grasses for livestock or to prompt animal movement during hunting expeditions, has been found to have mixed impacts on ecosystems services as it may potentially reduce water regulation (Harden, 2006), while 
increasing other ecosystems services such as carbon storage and biodiversity (Farley et al. 2013; Keating, 2007).

Similar to many PES programs (Naem et al., 2015), the PSB contract is not directly linked to specific ecosystem service outcomes, but rather stipulates a set of land-use restrictions intended to produce the desired conservation benefits, namely biodiversity conservation, water provision and carbon storage (MAE, 2009). In signing the PSB contract, communities agree not to burn, hunt, practice agriculture, or introduce non-native species or any activities that may impact the conservation value of the designated area (note, these additional activities are ill-defined). In addition, participants agree to limit grazing in the páramo to less than semi-intensive levels, although no formal guidelines are given as to what constitutes semi-intensive levels (MAE, 2009).

As of February, 2013, PSB had signed 47 contracts with highland communities, encompassing approximately 42,000 hectares of land and 15,000 households. Contracts are for twenty years and payments are made twice a year to the community governing body on the condition that the communities conserve their páramo. Building on the contract conditions, communities are responsible for crafting appropriate management rules and transmitting these rules to all constituents. While PSB is ultimately responsible for overseeing compliance; communities are responsible for reporting any transgressions to PSB. Payments are intended to be used for community development projects in accordance with community investment plans (Krause \& Loft, 2013; MAE, 2012), however, in practice, some communities may distribute part or all of the payment directly to households (pers. comm. PSB officers, 2014). In our study, yearly payments to the communities averaged USD 19,932 (SD 10,138) and most communities used the funds for community development projects, combined with direct payments. 


\subsection{Case study communities}

\subsubsection{Case selection \& location}

This study examines the influence of PSB in Quichua indigenous communities located in the central highlands in the provinces of Tungurahua and Chimborazo (see figure 1). We chose to study the central highlands because the majority of PSB's work with communities in the páramo (68\%) has been in this region. The páramo in Tungurahua and Chimborazo is critical for providing water to the highland cities, and provides water for hydroelectric power in three provinces (Gortaire, 2012). The páramo is also home to many poor, rural residents who use the páramo for grazing sheep and cattle, and agriculture activities.

This study compares páramo use in six participant communities and five non-participant communities. One of the challenges in assessing the impacts of voluntary programs such as PES is the potential for self-selection bias as those communities that choose to participate may be distinct from those that did not participate (Alix-Garcia \& Wolff, 2014; Miteva, et al., 2012). To account for this potential bias, our research design takes advantage of the gradual roll-out of the PSB program. PSB began working in the Central Andes in 2009 and continues to recruit communities. In our study, we compare communities that have been participating in the program to communities that are in the process of applying to enter.

Treatment and control communities were selected using quasi-experimental matching to control for possible observable sources of bias. Communities were selected based on the following criteria: identify as Quichua indigenous communities; households depend principally on farm-level activities for their livelihoods; communities had been using the páramo prior to 2008 when PSB entered the region; páramo is located at relatively similar altitudes and with similar topography; and, most residents can access the páramo by walking from their houses in less than 3 hours. The communities are 
representative of the distribution of community sizes and páramo sizes common to the region (please see table 1 for community characteristics). Similar to other páramo regions of Ecuador (Colpari, 2013), the communities are located in the poorer parishes where $85 \%$ of the population or more is unable to meet its basic needs (the average for the rural highlands is 45\%) (INEC, 2013). In addition, all PSB communities had been with the program for a minimum of two years (maximum of five), and had been under one regional PSB coordinator who had been with the program since its inception. 


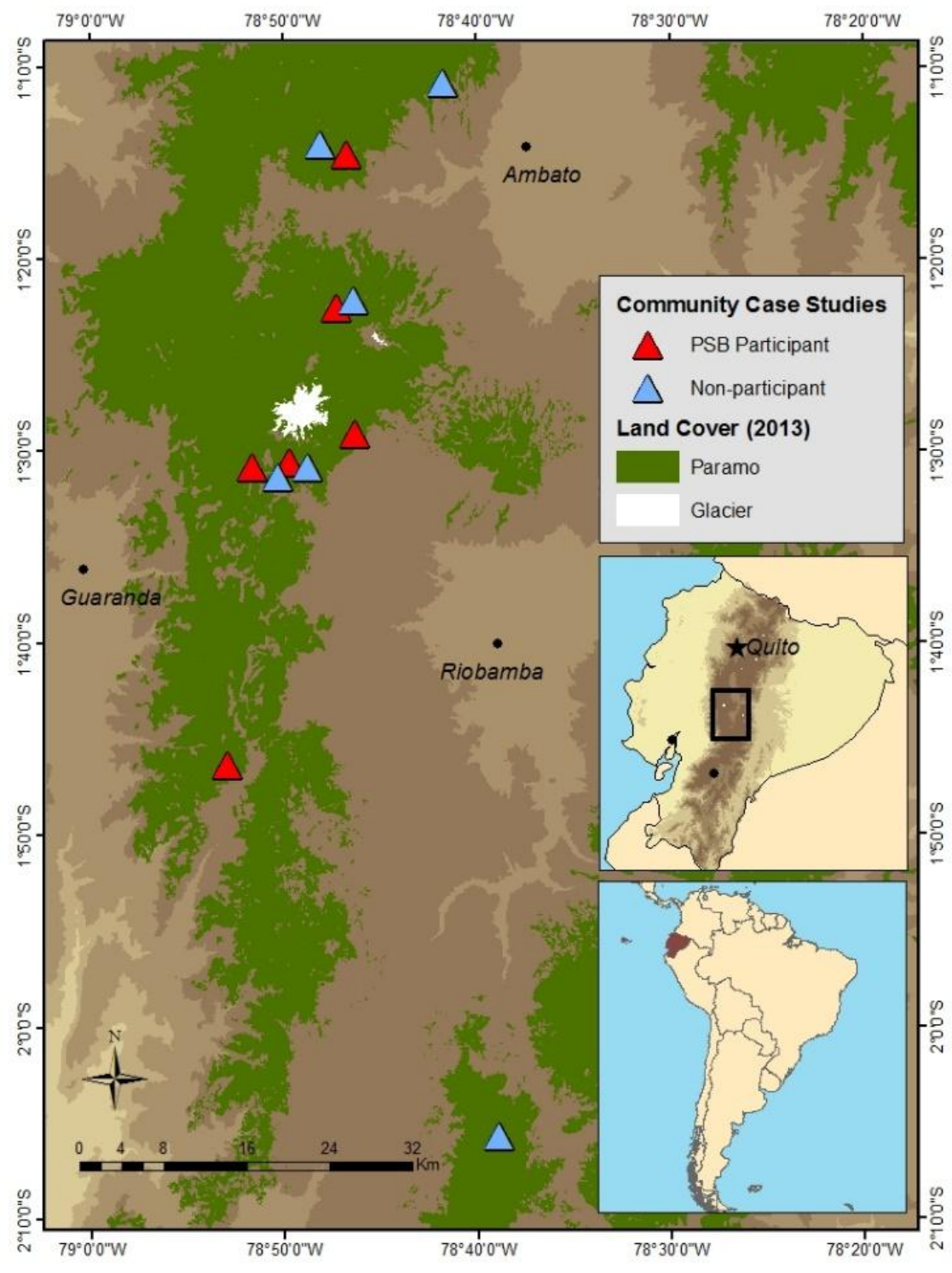

Figure 1. Case study location 
Table 1. Community characteristics

Participant Communities

Non-participant Communities

\begin{tabular}{|c|c|c|c|c|c|c|c|c|c|c|c|}
\hline & A & B & C & D & E & $\mathbf{F}$ & G & H & $\mathbf{I}$ & J & K \\
\hline Intervention (\# semesters) & 6 & 6 & 9 & 6 & 5 & 10 & NA & NA & NA & NA & NA \\
\hline Payment (\$/year) & 37,735 & 11,414 & 25,523 & 11,379 & 16,671 & 16,872 & NA & NA & NA & NA & NA \\
\hline Páramo Size (Ha) & 3,500 & 1,079 & 1,387 & 419 & 823 & 1,370 & 2,690 & 1,170 & 1,150 & 564 & 700 \\
\hline \# Households & 48 & 18 & 197 & 300 & 35 & 500 & 26 & 45 & 335 & 34 & 201 \\
\hline $\mathrm{HH}$ interviewed & 28 & 15 & 50 & 50 & 20 & 49 & 20 & 37 & 50 & 30 & 50 \\
\hline$\%$ interviewed & 58 & 83 & 25 & 17 & 57 & 10 & 77 & 82 & 15 & 88 & 25 \\
\hline Wealth index ${ }^{a}$ & -0.560 & -2.428 & 0.394 & 0.914 & -0.506 & -0.522 & -1.153 & -1.634 & 0.742 & -0.157 & -1.868 \\
\hline Poverty $(\%)^{b}$ & 85 & 99 & 95 & 85 & 85 & 93 & 93 & 85 & 95 & 85 & 85 \\
\hline Organization index ${ }^{a}$ & 0.947 & 0.947 & -0.148 & 1.459 & 0.009 & -1.358 & -0.428 & 0.708 & -0.295 & 0.708 & -0.552 \\
\hline
\end{tabular}

${ }^{a}$ See Table 2 for variable definition. ${ }^{b}$ Percentage of population living in poverty in the Parish where community is located (INEC, 2013) 


\subsubsection{Community land-use and governance characteristics}

Similar to many communities in the region, the residents in our study communities established their communal lands in the 1960 s and 1970 s as various stages of Ecuador's Agricultural Revolution broke up large haciendas and permitted indigenous and mestizo (of mixed Spanish and indigenous descent) laborers to purchase lands communally (Korovkin, 2002). While all study communities have recognized informal titles, not all of the communities have current official titles in hand. ${ }^{2}$

Across all communities, residents derive their livelihoods principally from agriculture and grazing. At lower elevations, households maintain individual parcels for household agriculture and animals. At higher elevations, the páramo has historically been used collectively for extensive grazing, housing materials, fuel, and medicinal uses. These collective lands, although rarely the main source of income for families, can be an important part of a household's livelihood portfolio, and are an important seasonal resource for some families (particularly in times of drought) (Alban \& Arguello, 2004; Bremer et al. 2014; Hofstede et al., 2014).

By law, each community is governed by an elected "executive body" that represents the community in all external relations with governmental and non-governmental organizations, and is charged with governing the day-to-day activities in the community. The executive body works with the community to make budgetary decisions, organize community assembly meetings and mingas (work parties), create and enforce community norms and rules, and mediate conflicts (Korovkin, 2002).

In our case study communities, all communities recognized at least one páramo-use rule, namely a ban on burning the páramo, however, communities differed in rules regarding grazing in the páramo. In our sample, six communities had previously devised grazing restrictions for the páramo. The

\footnotetext{
${ }^{2}$ Legal title to communal lands is a pre-requisite for entering into PSB. At the time of our study, two of the non-PSB communities did not have legal title and were working on filing the paperwork to have their informal titles legally recognized.
} 
communities had crafted these rules at least ten years prior to 2013 , with the majority crafting rules circa 2000.

The PSB contracts are the most direct formal rules by the government to regulate páramo use. Ecuador does not have a national law to protect the páramo (Morales \& Rivadeneira, 2011). With the exception of a ban on burning (explicitly applied to páramo in $2014^{3}$ ), national conservation laws largely consist of general stipulations to protect fragile ecosystems and biodiversity, many of which are weakly enforced (Echeverría \& Suárez, 2013; Esty \& Porter, 2001; Morales \& Rivadeneira, 2011). In our case study communities, all communities had received some education on the importance of the páramo, and all had received some sort of technical assistance for agricultural development. None, however, had participated in a payment program prior to PSB.

\section{Methods}

\subsection{Description of variables}

\subsubsection{Dependent variable}

In our assessment of behavioral change, our outcome of interest is the household decision to stop grazing animals (cows and sheep) in the collective páramo. Specifically, we asked if the household had grazed animals in the past year and if the household used the páramo for grazing in 2008 as compared to 2013 (please see section 4.2 for a more complete description of how this information was gathered).

We chose to focus specifically on grazing based on discussions with PSB extension agents, and other stakeholders, on the principal threats to the páramo, and results from a previous survey on communal land-use practices administered to leaders in participant and non-participant communities

\footnotetext{
${ }^{3}$ Note that our research found that the majority of communities already had rules prohibiting burning prior to the formal ban (which was established after our research was conducted). See authors 2015.
} 
across the Ecuadorian highlands (Authors 2015). ${ }^{4}$ The survey found that relatively few communities were using the páramo for agriculture (only $30 \%$ ), whereas $63 \%$ had animals grazing in the páramo. The survey also found that leaders in PSB communities most often interpreted the contract conditions to mean a ban on all extractive páramo uses. Thus, while, PSB does not prohibit grazing, the majority of participants (31 out of 44) stated that PSB prohibited grazing; an additional three respondents said that grazing was restricted.

\subsubsection{Independent variables}

We adapt the IAD framework to consider how household attributes, communal governance conditions, and attributes of the resource influence land-use behavior, specifically, behavioral change (please see Table 2). At the household level, we include demographic and socioeconomic attributes, in addition to perceptions of the páramo in our analysis. Household attributes include the number of cows a household owns, area of pasture owned, relative wealth, distance of household to the páramo, age, and perceived value of the páramo (economic or environmental) (Anley, et al., 2007; Koontz, 2001; Robbins et al., 2009; Sommerville, et al., 2010). We expect that households with more cows and less land or wealth will be more dependent on the collectively owned páramo, and therefore, less likely to stop grazing. We also expect that older households and those that live farther from the páramo will be less likely to graze the páramo as their age may limit their ability to access the more remote lands.

In addition, we consider how household perception of the páramo (conservation or extractive values) influence land-use behavior. While the relationship between environmental beliefs and environmental action is complex and contested (Dietz et al., 2005; Stern, 2000), several studies suggest that resource users that perceive the conservation value or environmental benefits of a resource will be

\footnotetext{
${ }^{4}$ The survey included almost a complete census (44 of 47) of highland communities participating in PSB.
} 
more likely to engage in conservation-related activities (Agrawal, et al., 2015; Koontz, 2001). A number of scholars, however, question whether these autonomously motivated behaviors will continue, or be thwarted, under PES (Agrawal, et al., 2015; DeCaro et al, 2008; Rode et al. 2015). In our analysis, to assess household percpetions of the value of the paramo, we asked head-of-households an open-ended question about the principal benefits that the household receives from the páramo (households were probed for three). We coded the responses based on whether the household stated that the parramo provided environmental benefits (conservation and water were the principal benefits stated).

With respect to the contextual factors that may influence a household's grazing behavior, we divide the institutional attributes into two categories: formal institutions and communal governance institutions (Ostrom 2005). The formal institution in the analysis is the PSB contract that states that communities must reduce their grazing activities in the páramo. This is the principal treatment variable in the analysis. If PSB is successful, we expect that, controlling for the abovementioned factors, on average, more households in PSB communities will have stopped grazing the páramo between 2008 and 2013 than in the control communities. In selecting the case studies, we carefully considered if other formal institutions, such as resource use laws might also influence páramo behavior and vary across communities. Through an analysis of archival documents and interviews with key stakeholders from other governmental and non-governmental organizations we did not identify any other formal institutions that could affect only a sub-group of our sample.

Communal governance variables include the capacity to self-organize, history of land-use rules, monitoring activities, the perceived likelihood that illicit activities in the páramo would be caught, and sanctioning mechanisms (Andersson et al., 2014; Berkes et al., 1998; Gibson, et al., 2005; Ostrom, 1990). The capacity to self-organize was measured by the frequency that a community holds communal mingas, general assembly meetings, and the application of sanctions for non-participation in assembly 
meetings (Schmitt, 2010). History of land-use rules was measured by whether a community had established grazing restrictions prior to 2008. Grazing restrictions included restricting the number of animals allowed on the páramo, designating certain areas as reserves or completely prohibiting grazing.

To assess monitoring and enforcement, we asked whether the community had an internal organized system for monitoring páramo use and if they had an established sanctions for any illicit páramo behavior. We also asked whether a household considered it likely that a rule-breaker would be caught for illicit use of the páramo. Monitoring and sanctioning mechanisms and the perceived likelihood of being caught were significantly associated $\left(X^{2}=104.13, p=0.000, n=398\right)$, as households in communities with internal monitoring and sanctioning mechanisms were more likely to think that a rulebreaker would be caught.

Based upon previous work in community resource management, we hypothesize that those communities that have greater capacity to self-organize and monitor and enforce páramo use restrictions will be best able to transmit PSB contract conditions regarding páramo use to the households (Andersson et al., 2014; Berkes et al., 1998; Gibson, et al., 2005; Ostrom, 1990). We are uncertain how previous grazing restrictions will influence land-use behavior. If communities had restricted grazing prior to entering PSB, one would assume that PSB would attain few additional gains with respect to household grazing behavior. However, previous literature suggests that formal restrictions, such as those placed by PSB could potentially thwart locally-devised rule systems (Cardenas, et al., 2000; Vatn, 2010), or provide added support and legitimacy to local rules (Bremer, et al., 2014).

As explained in section 3.2.1, we have attempted to minimize biophysical differences by focusing on one particular resource system (páramo). All páramo is located in the same central region of the Andes and at roughly the same elevation (3,700 to 4,200 meters). In the case study communities, 
the main physical variation among communities is páramo size. ${ }^{5}$ On average, PSB communities had slightly larger páramos and greater populations; however, both participant and non-participant communities spanned a range of community sizes which is typical of the highland communities in the region.

\footnotetext{
${ }^{5}$ Note that we are unable to assess more sophisticated biophysical features such as slope because of lack of appropriately georeferenced data on the location of the páramo lands for non-participant communities.
} 
Table 2. Description of variables

Variable

Outcome

Graze in 2013

Graze in 2008

Household attributes

No. of cows

Area pasture

Wealth index

Distance to páramo

Age

Perception páramo
Variable construction

Report by head of household whether the household grazes cattle or sheep in the communal páramo in 2013. Dichotomous, coded as Yes if the household was grazing in 2013

Report by head of household whether the household grazed cattle or sheep in the communal páramo in 2008 (recall question). Dichotomous, coded as Yes if the household was grazing in 2008

Report by head of household on the total number of cows that a household owns.

Report by head of household on the total number of hectares of páramo that a household holds.

Household wealth level based on report by head of household of having: 1) electricity, 2) running water, 3) flush toilets, 4) vehicles, 5) motorcycles, 6) television, 7) gas stoves, and 8) cement floors. Using principal component analysis, the 8 variables were weighted with the first component vector of each normalized variable. The index has mean 0, and ranges from -2.41 to 2.53 (Hayes, et al. 2015).

Report by head of household on the minutes walking from house to closest edge of páramo.

Head of household age in years

Report by head of household whether he/she perceives environmental benefits (i.e. water provision, biodiversity) from having a páramo. Dichotomous, coded as Yes if he/she perceives environmental benefits.

\section{Contextual factors: formal institutions}

PSB (Program Socio Dichotomous variable coded as Yes, if the household resides in a PSB participant Bosque) community, and No if resides in a non-participant community.

\section{Contextual factors: communal governance}


Self-organization Community organization level based on: 1) \# of communities' assemblies per index year, 2) \# mingas (traditional communal work) per year, and 3) if there are monetary sanctions for members that don't assist to assembly meetings. Using principal component analysis, the 3 variables were weighted with the first component vector of each normalized variable. The index has mean 0 , and ranges from -1.65 to 3.68 (Hayes, et al. 2015).

Rule history

Report by leaders and focus groups on whether a community had established grazing restrictions prior to 2008. Dichotomous, coded as Yes if community had prior rules

Monitoring and Report by leaders and focus groups on whether community had an organized enforcement system to monitor páramo activities and community prescribed sanctions for non-compliance. Dichotomous, coded as Yes if community had both monitoring and sanctions.

Perceive catch

Report by head of household whether he/she perceives if it is likely that someone would be caught if the person does not obey a communal rule regarding the use of páramo. Dichotomous, coded as Yes if he/she perceives that someone is likely to get caught

\section{Contextual factors: biophysical}

Population density No. of households in a community per hectare of páramo that a community collectively holds. 


\subsection{Data gathering}

\subsubsection{Household questionnaire}

In each case study community, we administered a household questionnaire (please see Appendix A). Houses in highland communities are often dispersed; different clusters are located higher up the mountain and others closer to the community center. Households were selected based upon a sampling process that worked with community leaders to map out the location of the households and stratify houses according to their proximity to the páramo. Within each cluster of houses, a relative percent was randomly selected to be interviewed. The male or female head of household was asked to respond to the questionnaire about household activities ( $50 \%$ of the respondents were female). In the smaller communities $(n<50)$, we administered the questionnaire to a minimum of 50 percent of the households, in the larger communities, we interviewed a minimum of 10 percent of the households (see table 1). In total, we interviewed 399 households (a $4 \%$ margin of error for the total sample at a $95 \%$ confidence level).

The questionnaire was orally administered by trained local interviewers with expertise in highland communities. Interviewers were instructed to present themselves as social-science researchers interested in the livelihood and land-use activities in the region. Interviewers were instructed to clearly state that they had no alliances with governmental or non-governmental organizations working in the region and that all interviewee responses would be confidential. Interviews were conducted in Spanish and included closed and open-ended questions about the activities of the household including land-use practices and livelihoods, use of the páramo, and participation in governance activities. PSB respondents were also asked about their knowledge and perceptions of the impact of the program. Questions regarding PSB, however, were at the end of the interview so as not to contaminate participant response. 
Páramo use was assessed by a set of questions that asked: (i) the extent to which a household used the páramo in 2008 as compared to the present (2013); (ii) whether the household grazed cattle or sheep in the páramo in 2008; (iii) whether the household grazed cattle or sheep in the páramo in the present day (2013); and (iv) in the present day, the average number of cows and sheep that the household grazed in the páramo on a yearly basis. Grazing behavior in the páramo is not necessarily consistent throughout the year. The survey specifically asked the respondent about their grazing behavior over the entire year, and explicitly asked where the respondent's grazed livestock in the dry season, and during times of drought.

We recognize the limits of using self-reports to assess páramo use, and particularly past páramo use (Thornberry \& Krohn, 2000; Tourangeau \& Yan, 2007). In addition to assurances about the confidentiality of their responses, we aimed to increase the reliability of the respondents answers by asking several questions that positioned páramo use as a common livelihood strategy and gave respondents both closed and open-ended opportunities to discuss if and how they use the páramo and how their use had changed (Schaeffer \& Presser, 2003; Thornberry \& Krohn, 2000). To address memory failure in the recall questions, interviewers were instructed to establish a timeframe of reference for each respondent (Raphael, 1987; Schaeffer \& Presser, 2003). In addition, for recall questions, rather than ask about the number of animals a household grazed in the collective páramo in the past, we asked about grazing behavior in terms of gradients of use (more today or less today) as this would be easier to recall. Later, these gradients of use were triangulated with other land use responses (from close and open-ended questions) in order to create the binary variables.

\subsubsection{Triangulation of household stated behavior}


To further validate our questionnaire results, we triangulated the household information with focus group discussions, key informant interviews, and an assessment of the use and condition of the páramo. Focus groups discussed community governance, livelihoods and land uses. During discussions, interviewers created a timeline to establish key events and identify an event that occurred approximately five years earlier (2008). These events were then used to help survey respondents recall earlier practices. Members also drew a map of the community and páramo lands, and discussed the governance issues on the communities' lands. The focus groups provided background information in which to contextualize the household interviews and the mapping was used to identify the boundaries of the community's páramo, verify principal land-uses and principal access routes to the páramo.

The páramo assessment was a rapid field assessment to identify current land-uses in the páramo and the state of degradation. A biologist with expertise in páramo systems walked a set of transect lines that were purposefully selected to cover the various land-uses and land-covers in each páramo and prioritize more accessible areas (Peralvo, 2013). The transect lines started at the top of a community's páramo and moved toward lower elevations and evidence of cattle, sheep and fires were documented along the lines. Georeferenced samples were taken every 500 meters, or less if the landcover or land-use changed within the 500 meter line. In each sample, 4 square plots of $1 \mathrm{~m}^{2}$ were used to assess plant species diversity, percent of plant cover, and signs of degradation. The páramo assessment is limited in its ability to measure páramo use as it is based only on evidence at one point in time, nonetheless, the observation of current or recent grazing activity helps to further verify the focal group and household information on the overall extent to which community members use the páramo.

\subsection{Analysis}


The analysis is divided into three sections. In the first section, we examine the average impact of the program on household grazing behavior. We use the difference in differences (DID) framework to estimate the treatment effect of PSB on grazing (Imbens \& Wooldridge, 2009). Here we take advantage of the gradual rollout of the PSB program and distinguish between "treated" households and "control" households. Treated units are those that enrolled in the PSB $\left(P S B_{i}=1\right)$ and the control units $\left(P S B_{i}=0\right)$ did not enroll yet at the time of the survey in 2013. In addition, we separate between the treatment period $(T=1)$ and the control period $(T=0)$. The treated period is at the point of time of our survey in 2013 and the control time is 2008 , hence five years prior to the survey when no one was enrolled in PSB. Our basic DID specification is given by equation (1), in which households are subscripted with $i$ in community $c$ and time is subscripted with $t$ :

$$
\text { grazing }_{c i t}=\alpha+\beta P S B_{i}+\gamma T_{t}+\delta^{c} \text { Treat }_{c i t}+\eta C_{c}+\varphi H_{i}+\varepsilon_{c i t}
$$

Our dependent variable is the dichotomous indicator grazing $_{c i t}$, assigning whether the household $i$ grazed their animals in the collective páramo $c\left(\right.$ grazing $\left._{c i t}=1\right)$ at time $t=\{2008,2013\}$. If household $i$ did not have animals grazing inside of the páramo at time $t$, the dummy is set equal to zero. The treatment effect variable Treat $_{i t}$ is equal to the multiplication of the $P S B_{i}$ and $T_{t}$. Hence, our parameter of interest is $\delta$ which shows the causal effect of the percentage change in grazing due to the PSB. In additional specifications, we further unpool the treatment effect by community indicators $c$, hence $\delta^{c}$, to test which communities have significant PSB effects. In robustness checks we further control for a set of variables $C$ that vary at the community level $c$ a set of variables $H$ that vary at the household level $i$. We direct the reader to tables 2 for further description of the communal and household variables used in the model. Finally, to account for community level peer effects as well as autocorrelation, we cluster our error term $\varepsilon_{c i t}$ at the community level. 
Difference-in-differences enables us to examine the average treatment and whether the average effect remains robust given a set of household and communal characteristics. It is less illustrative, however, of how an array of household and communal factors may also influence grazing as interpretation of these variables is conditional upon program participation. To understand how household attributes and community governance conditions also influence the decision to stop grazing, controlling for participation in PSB, in the second section of the analysis, we use logit models to identify how these variables shape grazing behavior. In this analysis, we are only interested in factors that produced a recent household decision to stop grazing animals in the collective páramo. Thus, the sample used in the logit models differs from the full sample included in the DID analysis. The logit models include only those households that had been grazing animals on the collective páramo in 2008 ( $n=210)$, thereby excluding households that had not been using the páramo for at least five years prior to the survey. The outcome in this analysis is a dummy variable, scored as a 1 if the household stopped grazing and scored as a 0 if the household stated that it continued grazing animals.

We present three logit models. In the first model, we examine how the socio-economic, demographic and cognitive attributes of the respective households influence the decision to stop grazing, controlling for population density. In the second and third models we introduce communal governance characteristics. In model 2 , we consider how community monitoring and enforcement mechanisms influence the decision to stop grazing. In model 3, we include whether the community had a history of grazing restrictions. Given the high correlation between perceived likelihood of being caught and rule history, we are unable to include both of these variables in model 3.

In all of the logit models, we report the coefficient, standard error term and the average marginal effect. The average marginal effect measures the average change in the probability that a 
household stops grazing, for a marginal change in the independent variable, holding all other variables at their observed values (Long \& Freese, 2014).

Finally, in the third section of the analysis, we further examine the conditions under which PSB has had the greatest impact. We combine qualitative analysis with the DID results of treatment effect by community to explore the interplay between PSB and communal governance.

\subsection{Study limitations}

In reading the results, we caution the reader to consider several potential limitations. First, in our research design and analysis, we have tried to account for differences between participant and nonparticipant communities, nonetheless, unmeasured unobservable variables (these would be in $\varepsilon_{\text {cit }}$.) could still be correlated with the treatment indicator and this would bias our DID estimates. This assumption is hard to circumvent as we do not have any viable instrumental variables for program enrollment. Following the intuition laid out by Altonji et al. (2000), we examined the potential for omitted variable bias by testing the robustness of our DID estimates to an array of community and household specifications and consistently found similar treatment effects. While the stability of our estimates across these different DID specifications is reassuring, we acknowledge that our research design cannot conclusively rule out the possibility that unobserved factors are influencing our estimates. It would, however, be difficult to come up with a story of an unobserved driver that is correlated with the treatment variable but uncorrelated with the set of community and household controls.

Second, grazing behavior is binary and does not trace change based on observations at several points in time. We have addressed recall limitations by using memory aids and triangulating our stated results with field observations. We recognize that the binary condition of completely stopping grazing does not fully capture potential reductions in grazing, however, we consider it to be a more accurate 
measure of grazing behavior than the specific number of cows a household grazed in the páramo in 2008 as compared to $2013 .{ }^{6}$ We expect to return to gather data to compare observed grazing patterns in 2013 to those at a later date (est. 2018).

Third, our analysis is limited in scope as we are considering only the effect of program participation on grazing behavior, not how particular attributes of the program may influence behavior (i.e. specific contract conditions, payment amounts or community investment plans), nor whether these behavioral changes are in fact producing the desired ecosystem services. Our analysis is also limited in scope in that we do not consider any of the social impacts. This is an issue we plan to address in the future.

Finally, analysis of community governance institutions is limited by the relatively small number of communities that met the quasi-experimental design selection criteria for the study. Thus, the findings provided an initial understanding of the potential ways in which communal institutions may interact with external payment programs. We hope that this exploratory analysis sparks further study of the relationship between conditional payments programs, and external intervention more broadly, and local governance institutions.

\section{Results}

\subsection{DID analysis of the impact of PSB on grazing behavior}

The DID results indicate that PSB has significantly reduced the number of households grazing in collective lands (see Table 3$)^{7}$. Model 1 shows an unconditional DID specification, and model 2 shows the conditional DID results in which we control for community and household variables. Both models

\footnotetext{
${ }^{6}$ Note that in interviews, no household stated that they had increased the number of cows in the collective páramo.

${ }^{7}$ See appendix B for descriptive statistics and appendix C for a correlation table.
} 
indicate that, on average, PSB has significantly reduced the number of households grazing in participant communities as compared to those communities that have yet to participate in the program. It is important to note that across participant and non-participant communities, there was a reduction in the percent of households that grazed in the collective lands in 2008 as compared to 2013 (see figure 2). The DID model 2 results, however, indicate that participation in PSB reduced the number of households grazing by an additional $12 \%$ than would have otherwise been predicted $(\delta=-0.117 ; 95 \%$ Confidence Interval: [-21.4\%, -2.1\%]). While several household and community attributes are significant conditional on the treatment, the treatment effect is robust (please see appendix $D$ for the results where we unpool the effect of PSB by community, $\delta^{c}$ ).

The DID results are further supported by household accounts of grazing and the field assessment of páramo use in 2013. In interviews with PSB households, 28\% (52 households) said that they made changes in their use of the páramo as a result of the community participating in PSB. Of those households that stated that they made changes, $87 \%$ stated that they moved their animals to more intensely used lower land outside of the páramo. In addition, $64 \%$ sold their animals (note that these categories are not mutually exclusive), and while several households stated that they had to rent or buy pastureland (8\%), very few (1\%) stated that they used a different páramo.

The results of the páramo field assessment, while unable to confirm behavioral change, corroborate household reports of páramo use in 2013. In 2013, a significantly greater proportion of páramo land in non-participant communities showed recent evidence of cattle as compared to participant communities (15.3\% compared to $3.9 \%$ respectively; Pearson chi square $=18.015, p=.000$ ). Grazing was observed in all non-participant communities, the maximum number of animals observed was 86. In contrast, in PSB communities, two communities did not show any evidence of grazing and the maximum number of animals observed was four. 
Table 3: Differences-in-Differences Results of the effect of participating in PSB on grazing outcomes.

\begin{tabular}{|c|c|c|c|c|c|c|}
\hline & \multirow{2}{*}{\multicolumn{3}{|c|}{ Model 1}} & \multirow{2}{*}{\multicolumn{3}{|c|}{ Model 2}} \\
\hline & & & & & & \\
\hline & Coeff. & Std err. & $\mathrm{t}$ & Coeff. & Std err. & $\mathrm{t}$ \\
\hline Treat & -0.117 & $0.049 * *$ & -2.40 & -0.117 & $0.049 * *$ & -2.40 \\
\hline Time & -0.314 & $0.034 * * *$ & -9.04 & -0.314 & $0.034 * * *$ & -9.04 \\
\hline PSB & -0.030 & 0.050 & -0.60 & 0.005 & 0.050 & 0.12 \\
\hline Population density & & & & -0.192 & $0.082 * *$ & -2.36 \\
\hline No. of cows & & & & 0.020 & $0.005^{* * *}$ & 3.93 \\
\hline Area pasture & & & & -0.009 & 0.009 & -1.02 \\
\hline Wealth Index & & & & -0.003 & 0.018 & -0.19 \\
\hline Distance to páramo & & & & -0.000 & 0.000 & -1.57 \\
\hline Age & & & & 0.002 & 0.001 & 1.51 \\
\hline Perception páramo & & & & -0.109 & $0.037^{* * *}$ & -2.92 \\
\hline Self-organization & & & & 0.062 & $0.027 * *$ & 2.28 \\
\hline Perceive catch & & & & 0.091 & $0.052^{*}$ & 1.74 \\
\hline Constant & 0.556 & $0.036 * * *$ & 15.26 & 0.497 & $0.092 * * *$ & 5.36 \\
\hline $\mathrm{N}$ & 776 & & & & 776 & \\
\hline R-Squared & 0.22 & & & & 0.17 & \\
\hline
\end{tabular}




\subsection{Influence of household and communal factors on grazing}

The DID results indicate that, on average, PSB is providing an additional reduction in grazing across participant communities, however, other household and communal factors also influence grazing. As shown in figure 3, households in participant and non-participant communities have stopped grazing, nonetheless, reduction in grazing is not uniform across communities.

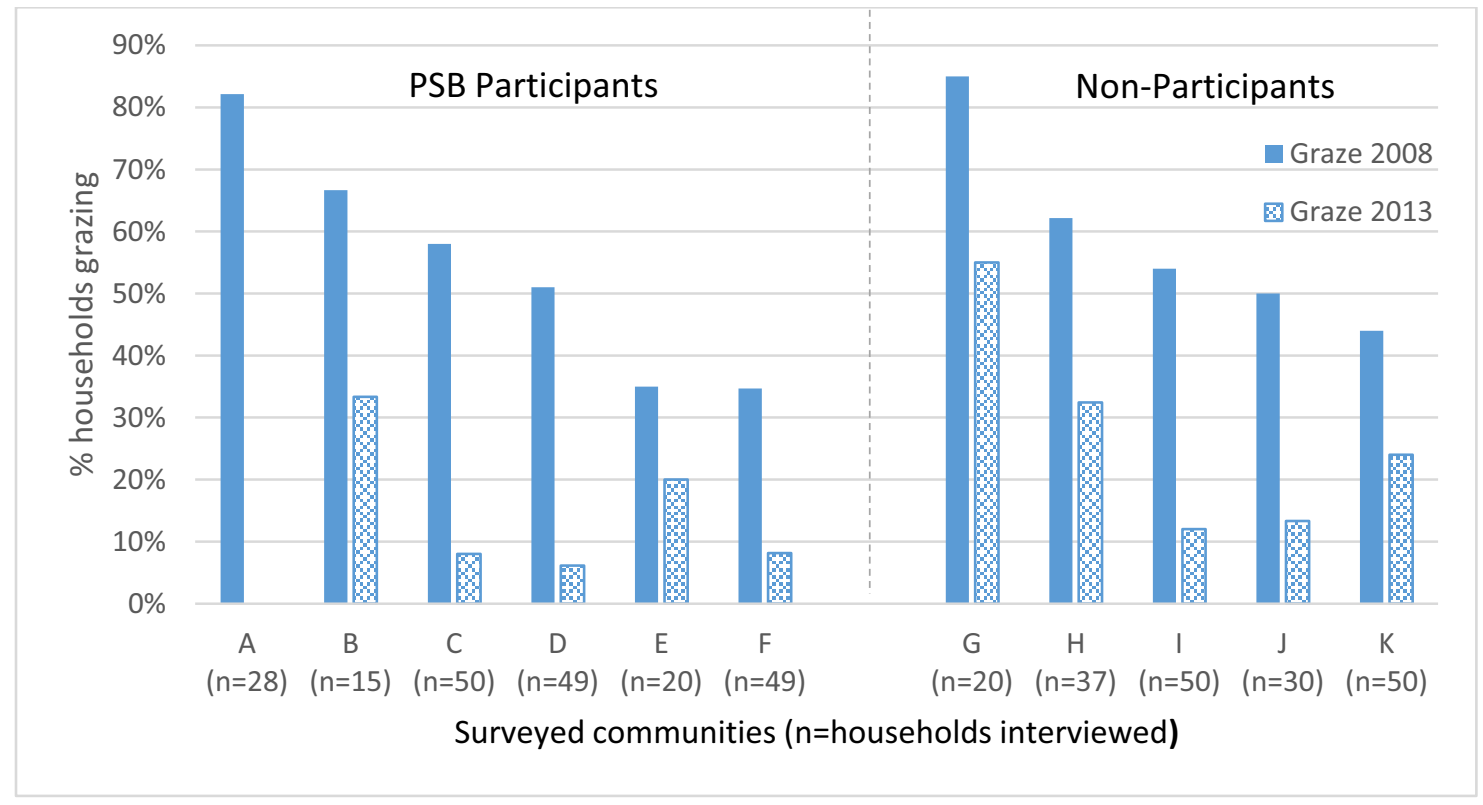

Figure 2. \% households grazing in 2008 and 2013 by PSB participant and non- participant communities

Logit models facilitate the analysis of how household and communal characteristics also shape grazing behavior and account for some of the variation in behavioral change across communities (see table 4). Similar to the DID analysis, the logit models show that holding all other variables at their observed values, on average, residing in a PSB community increases the probability that a household stops 
grazing. ${ }^{8}$ The model also shows that other independent variables are important factors influencing the decision to stop grazing, regardless of participating in PSB.

At the household level, the three models show that the socio-economic and demographic variables generally follow as predicted; households that have greater dependency on the land are more likely to continue to graze the páramo. Wealthier and older households are more likely to have stopped grazing in the páramo in the last five years. Likewise, those with more cows are significantly less likely to have stopped grazing, although the amount of pasture land owned by the household does not significantly influence grazing behavior. Household distance-to-páramo and population density are also not significant.

In models 2 and 3 household perceptions of the páramo are also significant. These models show that, holding all other variables at their observed values, on average, those households that believe that the páramo offers environmental benefits such as biodiversity and/or water are more likely to have stopped grazing in the collective páramo.

With respect to the association between a community's governance characteristics and the decision to stop grazing the collective páramo, the results indicate that governance capacities of the respective communities significantly affect the likelihood that a household stopped grazing the páramo. Models 2 and 3 indicate that the higher the self-organization index score, the more likely that a household has stopped grazing. Holding all other variables at their observed values, on average, the marginal effect of the self-organization is 0.091 (95\% Cl: $[0.011,0.170])$ for model 2 , and $0.266(95 \% \mathrm{Cl}$ : $[0.142,0.390])$ for model 3 .

\footnotetext{
${ }^{8}$ Please note that the DID results include household and communal variables; however, the interpretation of these variables is conditional on participation in PSB. Furthermore, the sample includes a number of households that never used the páramo. Therefore, while the results are similar to the logit, they cannot be directly compared.
} 
As shown in model 2, the perceived likelihood of getting caught also influences the likelihood a household to stopped grazing. Holding other variables at their observed values, the results indicate that on average, a change in the perception to get caught increases the probability that a household stopped grazing from $63.6 \%$ to $82.3 \%$, an increase of 18.7 percentage points (95\% $\mathrm{Cl}$ : [7.2, 30.2]).

Finally, as shown in model 3, a history of grazing restrictions is significant. Households in communities with a history of grazing rules are more likely to have stopped grazing. Holding other variables at their observed values, if a community has a history of grazing restrictions, on average, the probability that a household stopped grazing increases from $43.8 \%$ to $80.3 \%$, an increase of 36.5 percentage points $(95 \% \mathrm{Cl}:[22.2,50.9])$. In contrast, in this same model, PSB increased the likelihood that a household stopped grazing by 17.6 percentage points $(95 \% \mathrm{Cl}:[6.3,29.0]$. 
Table 4. Decision to stop grazing

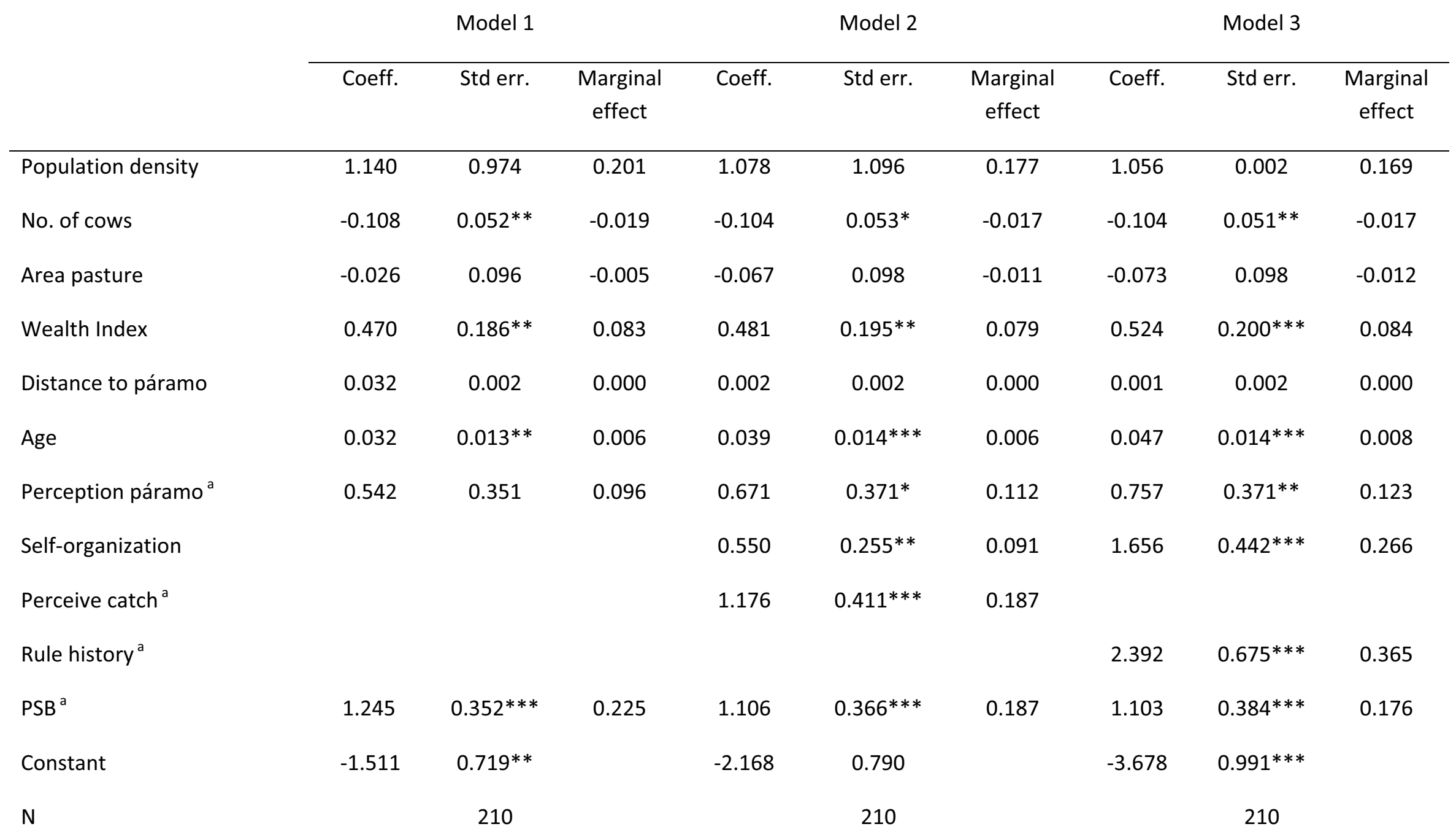




$\begin{array}{lccc}\text { Likelihood ratio test } & 35.94 * * * & 48.12 * * * & 54.55^{* * *} \\ \text { McFadden's Pseudo } \mathrm{R}^{2} & 0.140 & 0.187 & 0.212 \\ \text { AIC } & 238.6 & 230.4 & 224.0 \\ \text { Overall correct predictions } & 73.33 \% & 74.76 \% & 75.71 \%\end{array}$

Dependent variable: Stop grazing. ${ }^{*}, * *$, and ${ }^{* * *}$ indicates that the coefficient is significant at the $10 \%, 5 \%$ and $1 \%$ level respectively

${ }^{a} \mathrm{dy} / \mathrm{dx}$ is for change of the dummy variable from 0 to 1 


\subsection{Exploration of the interplay between PSB and communal governance institutions}

Logit results suggest that governance factors, irrespective of participation in PSB, significantly influence grazing behavior. To understand how these factors may facilitate the implementation of PSB, we use bivariate statistics and qualitative findings to identify how communal governance characteristics influence the transmission of PSB conditions to community members and grazing behavior within the subsample of participant communities. First, bivariate results indicate that households living in more organized communities are more likely to have knowledge of the PSB contract conditions (restrictions and benefits). While the majority of households (90\%) knew that the community was participating in PSB, those households living in more organized communities were better able to explain the contract conditions ( $73 \%$ compared to $45 \%$ respectively, $x^{2}=5.09, p=0.000, n=211$ ).

Similarly, within PSB communities, those communities that had a history of grazing restrictions prior to 2008, had greater reductions in grazing in 2013 as compared to those communities without prior grazing restrictions ( $88 \%$ compared to $71 \%$ respectively; $x^{2}=5.09, p=0.024, n=111$ ). While selforganization and sanctions are not statistically significant, the findings are in the expected direction, with a greater reduction in grazing in PSB communities that are more organized and in those communities with sanctioning mechanisms $\left(t=1.077, p=0.284 ; x^{2}=0.474, p=0.491\right)$.

The bivariate findings echo the qualitative findings of the ways in which community governance characteristics may enhance the impact of PSB. For example, the DID results found that PSB was particularly effective in one community (community A, please see appendix D). Community $A$ is a highly organized community with monthly assembly meetings and weekly work parties. Prior to participating in PSB, the community had begun to craft some land-use rules with respect to the páramo (specifically, it was forbidden to hunt and practice agriculture), however, grazing was still permitted. According to 
interviews with community leaders and focus group discussions, upon entering PSB, the community changed the páramo rules to explicitly prohibit grazing and began monitoring the rules on a rotating basis by community members (those that fail to monitor must pay a USD 20 fine). In focus group discussions, residents stated that while they had rules before, PSB helped to clarify the rules. Specifically, leaders stated that under PSB they were working to remove all livestock from the collective páramo.

It is important to note that the relationship between PSB and rules may not be unidirectional; household survey responses and focus group discussions indicate that just as PSB benefits from existing communal institutions, communal institutions also benefit from participation in PSB. In the survey of PSB participants, $72 \%$ of households stated that participation in PSB helped the community to further clarify their land-use rules, and $89 \%$ percent stated that due to participation, their community leaders were better able to look after the needs of the community $(n=188)$. Key informants and focus group discussions also noted that in some cases, the rules were now taken more seriously as communities would have to pay a penalty for non-compliance.

\section{Discussion}

\subsection{Impact of PES on household land-use behavior in the context of collective land management}

The results from Ecuador contribute to our empirical understanding of how PES operates in collective settings and its ability to prompt the adoption of new land-use behaviors. Counter to concerns that incentive programs broadly, and specifically Ecuador's PSB program, may not produce additional conservation behaviors (Bremer et al. 2014; Ferraro 2011; Pattanayak et al. 2010; Sommerville et al. 2010), the findings from our quasi-experimental comparison of participant and non-participant communities indicate that PSB is producing additional behavioral changes that would be unlikely to 
occur absent the program. Although the number of households grazing on collective páramo lands was decreasing across all communities in our study, the DID analysis found that participation in PSB reduced the number of households grazing livestock in the collective páramo by an additional $12 \%$. These results remained robust controlling for household and community characteristics, and are further supported by PSB household accounts of changes in grazing behavior due to participation in PSB and the field assessment of páramo use in 2013.

Much of the literature on PES in collective systems has raised concerns about the role of communal governance systems in implementing PES, and the ability of PES to support, rather than thwart, those systems (Clements et al. 2010; Corbera et al., 2009; Kerr et al. 2014; Muradian 2013; Sommerville et al. 2010). The results suggest that in collective PES contracts, communities are able to transmit PES regulations into appropriate rules that are implemented and enforced. Furthermore, the findings point to the importance of communal governance characteristics in facilitating PES, and in turn, the potential for PES to support collective resource management.

In an earlier study that surveyed the leaders from all of PSB communities in the Ecuadorian Andes ( $n=44)$, we found that $65 \%$ of participating communities crafted or strengthened their páramo rules as a result of participating in PSB (authors 2015). Similarly, other studies have also found that PES can support local governance systems (Bremer et al. 2014; Corbera et al. 2009; Sommerville et al. 2010). Here, our case study findings from focus group discussions and household interviews highlight how participation in PSB helped to support their communal resource management arrangements and clarify their páramo rules, particularly for grazing. Community members noted that participation in PES added greater legitimacy to their rules, in part because households feared the PSB sanctions from noncompliance. In addition, a strong majority believed that the program enabled community leaders to 
better meet their communities' needs, and $52 \%$ felt that the community was better off due to participation $(n=188)$.

The logit results and descriptive analyses further support the potential role of communal governance structures in implementing PES. The logit results indicate that a households living in communities with strong land management institutions are more likely to have stopped grazing. Bivariate statistics, while still exploratory, further demonstrate that households living in more organized communities were more likely to have greater understanding of the PSB contract conditions. Similarly, in PSB communities where members had previously established some level of grazing restrictions, more households were likely to have stopped grazing.

\subsection{PES in the context of other drivers of land-use behavior}

The results indicate that while PES may prompt households to change their land-uses, it is not the sole, nor necessarily the primary driver, of land-use behavior. Similar to other studies of land-use behavior, our study finds that in addition to PSB, socioeconomic, cognitive, local governance and broader contextual factors influence farmers' use of their collective páramo (Beedell \& Rehman, 2000; Chowdhury \& Turner, 2006; Fisher, 2012; Grothmann \& Patt, 2005; Hirsch, et al., 2011; Koontz, 2001; Robbins, et al., 2009; Sommerville, et al., 2010; Vatn, 2010; Vignola et al. 2010).

First, the logit results indicate that a household's dependency on the páramo, age, and the perceived value of the páramo (ecological or economic) influence the decision to graze animals. Holding all variables constant, including participation in PSB, households with more cows and poorer households were less likely to stop grazing in the páramo. As expected, older households were more likely to have stopped grazing. 
The findings also suggest that a household's perception of the natural resource may significantly influence their land-use decisions. While stated ecological value of the páramo for biodiversity or water conservation is a rough measure of environmental perception, it is noteworthy that perception of the páramo is a significant determinant of a change in land-use behavior in two of the three logit models. Although more research is needed on the relationship between environmental beliefs and action (Dietz 2005), the results support literature in social-psychology and behavioral economics that suggests that those that are autonomously or intrinsically motivated by beliefs will be more likely to perform a desired conservation activity (DeCaro \& Stokes 2008; Cetas \& Yasue, 2016).

Second, the logit results suggest that communal governance characteristics may potentially have a greater impact than PES program participation, and as noted above, may be instrumental in facilitating PES in collective systems. Irrespective of participating in PSB, those households living in communities with a greater capacity to self-organize, a history of grazing restrictions, and perceived application of those restrictions were more likely to have stopped grazing in the past five years. While the findings support previous research on the importance of local institutions in resource management (Agrawal, 2007; Berkes, et al., 1998; Coleman \& Steed 2009; Gibson et al., 2005; Ostrom, 1990; Persha et al. 2011), the results furthers contribute to our understanding of common-pool resource management by explicitly identifying how specific community governance attributes, namely the capacity to organize, resource-use rules, and local monitoring, influence household resource-use behavior (Andersson et al. 2014).

Lastly, it is important to note, that in addition to household and communal governance factors, there may be some broader contextual factors that are also influencing land-use decisions across rural communities in the Andes. To our knowledge, no studies have systematically examined recent socioeconomic trends occurring in these regions and how these trends may shape páramo use (Hofstede et 
al. 2014). Our focus group interviews and timelines of páramo use suggest that broader economic trends, technological changes and educational campaigns on the importance of the páramo may also be contributing to the general decline in páramo use that we see across participant and non-participant communities. In all eleven communities, focus groups explained that increasing costs of agricultural inputs such as fertilizer and pesticides, decreasing prices for said products, and poor soils of the remaining páramo lands made those lands less attractive for agriculture. While some noted an increasing dependence on dairy cattle, community members consistently stated that they now use improved pasture grasses and better breeds for more intensive dairy production, often on lower lands. Communities also noted that before they used the páramo grasses to a greater extent for fuel and housing materials, but that given new technologies, households depend less on the páramo for these products. Future research is needed to better understand how these broader contextual factors may be shaping páramo use and what this means for conservation policies and projects in the region.

\section{Conclusions: Policy insights and areas for future research}

Since the late 1990s, PES and related incentive-based programs have become increasingly prevalent as a tool for conservation in poor, resource-dependent communities (Kerr et al. 2014; Pascual et al. 2014). Despite its growing use, we have a limited understanding of the conditions in which PES may serve as an appropriate tool for conservation (Alix-Garcia et al., 2014; Kerr et al. 2014; Pattanayak et al. 2010; Wunder 2013). As one of the first national PES programs implemented on communal lands, the findings from Ecuador offer some important policy insights for the implementation of PES on collective lands and suggest venues for future research.

First, the findings suggest that PES can be an effective tool for conservation on communal lands, but it may be more effective in organized communities with a history of collective resource 
management institutions. While several authors have argued that additionality is dependent on getting those that were not previously engaged in conservation activities (Engel et al. 2008; Ferraro \& Pattanayak, 2006; Wunder 2005;), the results here indicate that communities already inclined toward managing their resource systems may produce greater gains. Recognizing the limits of a relatively small set of cases, the findings suggest that practitioners and scholars pay particular attention to the communal governance capacities prior to establishing a PES program. More organized communities were more likely to transmit the PES conditions to their households, and households living in PES communities with a history of land-use rules were more likely to stop grazing in the páramo.

Our results also suggest the potential for PES programs and local resource management institutions to be mutually reinforcing. Although a number of PES scholars, and researchers of communal resource management more broadly, have expressed concerns about the capacity of external interventions such as PES to support collective action for local resource management (Agrawal and Chhatre, 2007; Andersson et al., 2006; Barnes \& van Laerhoven, 2015; Cox et al., 2010; Clements et al., 2010; Kerr 2014; Muradian 2013; Ostrom, 1990, 2005; Sommerville et al. 2010), in the case of PSB, we did not find any evidence that the program thwarted local resource management initiatives. Rather, similar to previous research in the region (Bremer et al. 2014), our results found that community members considered PSB to have increased the legitimacy and clarity of the local governance institutions. Future research, however, is needed to tease out the complex interactions between community governance dynamics and the specific PES programmatic mechanisms that may be instrumental in supporting local resource management activities. Research is also needed to assess these governance and land-use trends over time to understand the role of communal governance capacity and PES in sustainable resource management. 
Second, the findings suggest that PES is not the only driver, nor necessarily the predominant driver, of behavioral change. Similar to other studies (Alix-Garcia et al., 2012, Arriagada et al., 2009, 2012; Clements \& Milner-Gulland, 2015), the results from this study found that PES had a significant, yet relatively modest impact on land-use. The results also indicated that impact may vary across and within communities. Our logit analysis identified how irrespective of PES, household dependency on the resource system and communal governance factors significantly influenced land-use behavior. At the household level, the finding that poorer households and those that more heavily used the páramo were less likely to have stopped grazing, irrespective of PSB, raises questions about compliance within PES communities. Recognizing that our analysis did not capture household reduction of páramo use, only elimination of grazing, the findings indicate the need to look more specifically at who within communities is more likely to comply with PES restrictions, and why. For policymakers it is important to understand the extent to which PES restrictions are applied across all community members, and whether collective payment programs are effective at prompting change from those that more heavily use the resource.

Finally, given the modest impacts of PES, the results suggest that policymakers and scholars need to further consider the utility of PES as a conservation tool when compared to other conservation programs, and a wider array of costs and benefits that may result from program implementation. While PES is often argued to be a desirable policy tool because of the environmental and social benefits it may provide (Pagiola et al., 2005; Wunder, 2005, 2013), we have limited empirical understanding of these benefits, and how they compare to the net benefits derived from other conservation programs (Adhikari \& Agrawal, 2013; Boerner et al. 2016; Naeem et al., 2015; Rico Garcia-Amado 2013). From an environmental standpoint more research is needed to better identify whether the environmental practices often prescribed under PES actually produce the desired environmental service (Naeem et al., 
2015). This is particularly true in páramo systems where a number of PES programs have been implemented with little certainty of how anthropogenic activities impact the ecosystem services (Farley et al. 2011; Farley et al. 2013; Keating 2007).

Research is also needed to explore the social impacts of PES. Behavioral changes and the desired environmental services are unlikely to be sustained if households perceive negative social impacts (Pascual et al. 2010). While there is some evidence that PES can provide livelihood benefits (Adhikari and Agrawal, 2013; Bremer et al. 2014; Pagiola et al. 2005; Wunder \& Alban, 2008), we need to understand the broader array of social impacts, specifically in how the costs and benefits of participation are distributed across resource users, and the possibility for said arrangements to create conflict within communities (Corbera et al. 2007; Kerr et al. 2014; Krause et al. 2013; Pascual et al. 2010; Rodriguez de Francisco et al. 2013).

Here, we have focused on the impact of PES on household land-use behaviors and have argued that PES cannot be considered in isolation of the communal governance dynamics that also shape resource management. If PES is to continue to promote sustainable resource management in resourcedependent communities, however, future research is needed to explore in greater depth the social and ecological impacts, particularly over longer time periods. We hope that the study findings prompt researchers and policymakers to delve further into the interactions between communal governance systems, PES programs and sustainable resource management. 


\section{References}

Adhikari, B., \& Agrawal, A. (2013). Understanding the social and ecological outcomes of PES projects: A review and an analysis. Conservation and Society, 11, 359.

Agrawal, A. (2007). Forests, governance, and sustainability: Common property theory and its contributions. International Journal of the Commons, 1, 111-136.

Agrawal, A., \& Chhatre, A. (2007). State involvement and forest co-governance: Evidence from the Indian Himalayas. Studies in Comparative International Development, 42(1-2), 67-86.

Agrawal, A., Chhatre, A., \& Gerber, E. R. (2015). Motivational crowding in sustainable development interventions. American Political Science Review, 109, 470-487.

Albán, M., \& Argüello, M. (2004). Un análisis de los impactos sociales y económicos de los proyectos de fijación de carbono en el Ecuador. El caso de PROFAFOR-FACE (Vol. 7): IIED.

Alix-Garcia, J. M., Shapiro, E. N., \& Sims, K. R. (2012). Forest conservation and slippage: Evidence from Mexico's national payments for ecosystem services program. Land Economics, 88, 613-638.

Alix-Garcia, J., \& Wolff, H. (2014). Payment for ecosystem services from forests. Annual Review of Resource Economics, Vol. 6, pp. 361-380.

Altonji, J. G., Elder, T. E., \& Taber, C. R. (2000). Selection on observed and unobserved variables: Assessing the effectiveness of Catholic schools. In: National bureau of economic research.

Andersson, K. P., Gibson, C. C., \& Lehoucq, F. (2006). Municipal politics and forest governance: Comparative analysis of decentralization in Bolivia and Guatemala. World Development, 34(3), 576-595.

Andersson, K., Benavides, J. P., \& León, R. (2014). Institutional diversity and local forest governance. Environmental Science \& Policy, 36, 61-72. 
Anley, Y., Bogale, A., \& Haile-Gabriel, A. (2007). Adoption decision and use intensity of soil and water conservation measures by smallholder subsistence farmers in Dedo district, Western Ethiopia. Land Degradation \& Development, 18, 289-302.

Arriagada, R., Sills, E., Pattanayak, S., \& Ferraro, P. (2009). Combining qualitative and quantitative methods to evaluate participation in Costa Rica's program of payment for environmental services. Journal of Sustainable Forestry, 28, 343-367.

Arriagada, R., Ferraro, P. J., Sills, E., Pattanayak, S. K., \& Cordero-Sancho, S. (2012). Do payments for environmental services affect forest cover? A farm-level evaluation from Costa Rica. Land Economics, 88, 382-399.

Barnes, C., \& van Laerhoven, F. (2015). Making it last? Analysing the role of NGO interventions in the development of institutions for durable collective action in Indian community forestry. Environmental Science \& Policy, 53, Part B, 192-205.

Basurto, X., \& Ostrom, E. (2009). Beyond the tragedy of the commons. Economia delle fonti di energia e dell'ambiente, 52, 35-60.

Beedell, J., \& Rehman, T. (2000). Using social-psychology models to understand farmers' conservation behavior. Journal of Rural Studies, 16, 117-127.

Berkes, F., \& Folke, C. (1998). Linking social and ecological systems for resilience and sustainability. In F. Berkes, C. Folke \& J. Colding (Eds.), Linking social and ecological systems : management practices and social mechanisms for building resilience (pp. 1-25). Cambridge, U.K. ; New York: Cambridge University Press.

Berkes, F., Folke, C., \& Colding, J. (1998). Linking social and ecological systems : management practices and social mechanisms for building resilience. Cambridge, U.K. ; New York: Cambridge University Press. 
Boerner, J., Baylis, K., Honey-Roses, J., Corbera, E., Ezzine-de-Blas, D., Ferraro, P., . . Wunder, S. (2016). Emerging Evidence on the Effectiveness of Tropical Forest Conservation. pdf. PlosOne. Available at: http://works.bepress.com/kathy_baylis/76/

Bremer, L. L., Farley, K. A., Lopez-Carr, D., \& Romero, J. (2014). Conservation and livelihood outcomes of payment for ecosystem services in the Ecuadorian Andes: What is the potential for 'win-win'? Ecosystem Services, 8, 148-165.

Buytaert, W., Celleri, R., De Bievre, B., Cisneros, F., Wyseure, G., Deckers, J., \& Hofstede, R. (2006). Human impact on the hydrology of the Andean paramos. Earth-Science Reviews, 79, 53-72.

Buytaert, W., \& De Bièvre, B. (2012). Water for cities: The impact of climate change and demographic growth in the tropical Andes. Water Resources Research, 48, w08503.

Cardenas, J. C., Stranlund, J., \& Willis, C. (2000). Local environmental control and institutional crowding out. World Development, 28, 1719-1733.

Cetas, E. R., \& Yasue, M. (2016). A systematic review of motivational values and conservation success in and around protected areas. Conservation Biology. doi:10.1111/cobi.12770

Chhatre, A., \& Agrawal, A. (2008). Forest commons and local enforcement. Proceedings of the National Academy of Sciences, 105, 13286-13291.

Chowdhury, R. R., \& Turner, B. L. (2006). Reconciling agency and structure in empirical analysis: Smallholder land use in the southern Yucatan, Mexico. Annals of the Association of American Geographers, 96, 302-322.

Clements, T., John, A., Nielsen, K., An, D., Tan, S., \& Milner-Gulland, E. (2010). Payments for biodiversity conservation in the context of weak institutions: Comparison of three programs from Cambodia. Ecological Economics, 69, 1283-1291. 
Clements, T., \& Milner-Gulland, E. J. (2015). Impact of payments for environmental services and protected areas on local livelihoods and forest conservation in northern Cambodia. Conservation Biology, 29, 78-87.

Coleman, E. A., \& Steed, B. C. (2009). Monitoring and sanctioning in the commons: An application to forestry. Ecological Economics, 68, 2106-2113.

Colpari, O. (2013). Territorios de páramo: Territorios en crisis. Ecuador: Rimisp

Corbera, E., Soberanis, C. G., \& Brown, K. (2009). Institutional dimensions of Payments for Ecosystem Services: An analysis of Mexico's carbon forestry programme. Ecological Economics, 68(3), 743761.

Cox, M., Arnold, G., \& Tomas, S. V. (2010). A review of design principles for community-based natural resource management. Ecology and Society, 15(4). 38. URL: http://www.ecologyandsociety.org/vol15/iss4/art38/

Crespo, P., Célleri, R., Buytaert, W., Feyen, J., Iñiguez, V., Borja, P., \& de Bièvre, B. (2010). Land use change impacts on the hydrology of wet Andean páramo eocystems. Status and Perspectives of Hydrology in Small Basins. IAHS Publ, 336.

DeCaro, D., \& Stokes, M. (2008). Social-psychological principles of community-based conservation and conservancy motivation: Attaining goals within an autonomy-supportive environment. Conservation Biology, 22(6), 1443-1451.

De Koning, F., Aguiñaga, M., Bravo, M., Chiu, M., Lascano, M., Lozada, T., \& Suarez, L. (2011). Bridging the gap between forest conservation and poverty alleviation: The Ecuadorian Socio Bosque program. Environmental Science \& Policy, 14, 531-542.

Deaton, A. (2010). Instruments, randomization, and learning about development. Journal of Economic Literature, 424-455. 
Dietz, T., Fitzgerald, A., \& Shwom, R. (2005). Environmental values. Annual Review of Environment and Resources, 30, 335-372.

Dougill, A. J., Stringer, L. C., Leventon, J., Riddell, M., Rueff, H., Spracklen, D. V., \& Butt, E. (2012). Lessons from community-based payment for ecosystem service schemes: From forests to rangelands. Philosophical Transactions of the Royal Society B-Biological Sciences, 367, 31783190.

Echeverría, H., \& Suárez, S. (2013). Tutela judicial efectiva en materia ambiental: el caso ecuatoriano. Quito: Centro Ecuatoriano de Derecho Ambiental.

Engel, S., Pagiola, S., \& Wunder, S. (2008). Designing payments for environmental services in theory and practice: An overview of the issues. Ecological Economics, 65, 663-674.

Esty, D., \& Porter, M. E. (2001). Ranking national environmental regulation and performance: A leading indicator of future competitiveness? In M. E. Porter, J. D. Sachs, P. K. Cornelius, J. W. McArthur \& K. Schwab (Eds.), The Global Competitiveness Report 2001-2002. New York: Oxford University Press.

Farley, K. A., Anderson, W. G., Bremer, L. L., \& Harden, C. P. (2011). Compensation for ecosystem services: An evaluation of efforts to achieve conservation and development in Ecuadorian paramo grasslands. Environmental Conservation, 38, 393-405.

Farley, K. A., Bremer, L. L., Harden, C. P., \& Hartsig, J. (2013). Changes in carbon storage under alternative land uses in biodiverse Andean grasslands: implications for payment for ecosystem services. Conservation Letters, 6(1), 21-27.

Farley, K. A., Kelly, E. F., \& Hofstede, R. G. (2004). Soil organic carbon and water retention after conversion of grasslands to pine plantations in the Ecuadorian Andes. Ecosystems, 7, 729-739. 
Ferraro, P. J. (2011). The future of payments for environmental services. Conservation Biology, 25, 11341138.

Ferraro, P., \& Kiss, A. (2002). Ecology: Direct payments to conserve biodiversity. Science, 298, 1718.

Ferraro, P. J., \& Pattanayak, S. K. (2006). Money for nothing? A call for empirical evaluation of biodiversity conservation investments. PLoS Biol, 4(4), e105.

Fisher, J. (2012). No pay, no care? A case study exploring motivations for participation in payments for ecosystem services in Uganda. Oryx, 46, 45-54.

García-Amado, L. R., Pérez, M. R., Escutia, F. R., García, S. B., \& Mejía, E. C. (2011). Efficiency of payments for environmental services: Equity and additionality in a case study from a Biosphere Reserve in Chiapas, Mexico. Ecological Economics, 70, 2361-2368.

Gibson, C., Williams, J., \& Ostrom, E. (2005). Local enforcement and better forests. World Development, $33,273-284$.

Goldman-Benner, R. L., Benitez, S., Boucher, T., Calvache, A., Daily, G., Kareiva, P., . . Ramos, A. (2012). Water funds and payments for ecosystem services: practice learns from theory and theory can learn from practice. Oryx, 46(1), 55-63.

Gortaire, F. S. (2012). El clima cambia, cambia tu tambien. Adaptacion al cambio climatico en comunidades del Chimborazo en Ecuador. Lima, Peru: Sociedad Peruana de Derecho Ambiental.

Grothmann, T., \& Patt, A. (2005). Adaptive capacity and human cognition: The process of individual adaptation to climate change. Global Environmental Change-Human and Policy Dimensions, 15, 199-213.

Harden, C. P. (2006). Human impacts on headwater fluvial systems in the northern and central Andes. Geomorphology, 79(3-4), 249-263. 
Hayes, T., Murtinho, F., \& Wolff, H. (2015). An institutional analysis of payment for environmental services on collectively managed lands in Ecuador. Ecological Economics, 118, 81-89.

Hirsch, P. D., Adams, W. M., Brosius, J. P., Zia, A., Bariola, N., \& Dammert, J. L. (2011). Acknowledging conservation trade-offs and embracing complexity. Conservation Biology, 25, 259-264.

Hofstede, R. (1995). Effects of livestock farming and recommendations for management and conservation of paramo grasslands (Colombia). Land Degradation \& Development, 6(3), 133147.

Hofstede, R., Calles, J., Lopex, V., Polanco, R., Torres, F., Ulloa, J., Vasquez, A., \& Cerra, M. (2014). Los paramos Andinos, que sabemos? Estado de conocimiento sobre el impacto del cambio climatico en el ecosistema páramo. Quito, Ecuador: IUCN.

Igoe, J., \& Brockington, D. (2007). Neoliberal conservation: A brief introduction. Conservation and Society, 5(4), 432.

Imbens, G., \& Wooldridge, J. (2009). New developments in econometrics. Lecture Notes, CEMMAP, UCL2009b.

INEC. (2013). Ecuador en Cifras. In: Instituto Nacional de Estadisticas y Censos.

Keating, P. L. (2007). Fire ecology and conservation in the high tropical Andes: observations from northern Ecuador. Journal of Latin American Geography, 43-62.

Kerr, J. M., Vardhan, M., \& Jindal, R. (2014). Incentives, conditionality and collective action in payment for environmental services. International Journal of the Commons, 8, 595-616.

Koontz, T. M. (2001). Money talks? But to whom? Financial versus nonmonetary motivations in land use decisions. Society \& Natural Resources, 14, 51-65.

Korovkin, T. (2002). Comunidades Indigenas: Economia de mercado y democracia en los Andes Ecuatorianos. Quito: Centro de Investigacion de los Movimientos Sociales Ecuador. 
Kosoy, N., Corbera, E., \& Brown, K. (2008). Participation in payments for ecosystem services: Case studies from the Lacandon rainforest, Mexico. Geoforum, 39, 2073-2083.

Krause, T., \& Loft, L. (2013). Benefit distribution and equity in Ecuador's Socio Bosque program. Society \& Natural Resources, 26, 1170-1184.

Liverman, D. (2004). Who governs, at what scale and at what price? Geography, environmental governance, and the commodification of nature. Annals of the Association of American Geographers, 94(4), 734-738.

Long, J. S., \& Freese, J. (2014). Regression Models for Categorical Dependent Variables Using Stata (Third ed.). College Station, Texas: Stata Press.

Madriñan, S., Cortes, A., \& Richardson, J. (2013). Páramo is the world's fastest evolving and coolest biodiversity hotspot. Frontiers in Genetics, 4, 1-7.

MAE. (2009). Acuerdo Ministerial Numero 115. In. Quito: Ministerio del Ambiente.

MAE. (2012). Socio Bosque. El Boletin informativo. In (pp. 5). Quito, Ecuador: Ministerio del Ambiente.

McAfee, K., \& Shapiro, E. N. (2010). Payments for ecosystem services in Mexico: Nature, neoliberalism, social movements, and the state. Annals of the Association of American Geographers, 100(3), 579-599.

Mercer, D. E. (2004). Adoption of agroforestry innovations in the tropics: a review. Agroforestry systems, $61,311-328$.

Miteva, D. A., Pattanayak, S. K., \& Ferraro, P. J. (2012). Evaluation of biodiversity policy instruments: what works and what doesn't? Oxford Review of Economic Policy, 28, 69-92.

Morales, M., \& Rivadeneira, S. (2011). El Ecuador requiere de un instrumento legal para promover la conservacion de sus páramos. In P. M. Vasconez, A. Castillo, s. Flores, R. Hofstede, C. Josse, S. 
Lasso, G. Medina, N. Ochoa \& D. Ortiz (Eds.), Paramo: Paisaje estudiado, habitado, manejado e institucionalizado (pp. 301-314). Quito: Editorial Universitaria Abya-Yala.

Muradian, R. (2013). Payments for ecosystem services as incentives for collective action. Society \& Natural Resources, 26, 1155-1169.

Muradian, R., Corbera, E., Pascual, U., Kosoy, N., \& May, P. (2010). Reconciling theory and practice: An alternative conceptual framework for understanding payments for environmental services. Ecological Economics, 69, 1202-1208.

Narloch, U., Pascual, U., \& Drucker, A. G. (2012). Collective action dynamics under external rewards: Experimental insights from Andean farming communities. World Development, 40, 2096-2107.

Naeem, S., Ingram, J. C., Varga, A., Agardy, T., Barten, P., Bennett, G., . . Wunder, S. (2015). Get the science right when paying for nature's services. Science, 347(6227), 1206-1207.

Ostrom, E. (1990). Governing the Commons: The evolution of institutions for collective action. New York: Cambridge University Press.

Ostrom, E. (2005). Understanding Institutional Diversity. Princeton, NJ: Princeton University Press.

Ostrom, E. (2007). A diagnostic approach for going beyond panaceas. Proceedings of the National Academy of Sciences of the United States of America, 104, 15181-15187.

Ostrom, E. (2009). A general framework for analyzing sustainability of social-ecological systems. Science, $325,419-422$.

Ostrom, E., Gardner, R., \& Walker, J. (1994). Rules, games, and common-pool resources: University of Michigan Press.

Ostrom, E., \& Nagendra, H. (2006). Insights on linking forests, trees, and people from the air, on the ground, and in the laboratory. Proceedings of the National Academy of Sciences, 103, 1922419231. 
Pagiola, S., Agostini, P., Gobbi, J., de Haan, C., Ibrahim, M., Murgueitio, E., . . Ruiz, J. P. (2005). Paying for biodiversity conservation services - Experience in Colombia, Costa Rica, and Nicaragua. Mountain Research and Development, 25(3), 206-211.

Pascual, U., Muradian, R., Rodriguez, L. C., \& Duraiappah, A. (2010). Exploring the links between equity and efficiency in payments for environmental services: A conceptual approach. Ecological Economics, 69(6), 1237-1244.

Pascual, U., Phelps, J., Garmendia, E., Brown, K., Corbera, E., Martin, A., . . Muradian, R. (2014). Social equity matters in payments for ecosystem services. Bioscience, 64(11), 1027-1036.

Pattanayak, S. K., Wunder, S., \& Ferraro, P. J. (2010). Show me the money: Do payments supply environmental services in developing countries? Review of Environmental Economics and Policy, 4, 254-274.

Peralvo, M. (2013). Protocolo de levantamiento de puntos en campo. In CONDESAN (Ed.). Quito, Ecuador: CONDESAN.

Persha, L., Agrawal, A., \& Chhatre, A. (2011). Social and ecological synergy: Local rulemaking, forest livelihoods, and biodiversity conservation. Science, 331, 1606-1608.

Petheram, L., \& Campbell, B. M. (2010). Listening to locals on payments for environmental services. Journal of Environmental Management, 91, 1139-1149.

Podwojewski, P., Poulenard, J., Zambrana, T., \& Hofstede, R. (2002). Overgrazing effects on vegetation cover and properties of volcanic ash soil in the páramo of Llangahua and La Esperanza (Tungurahua, Ecuador). Soil Use and Management, 18, 45-55.

Raphael, K. (1987). Recall bias: A proposal for assessment and control. International Journal of Epidemiology, 16, 4. 
Rico García-Amado, L., Ruiz Pérez, M., \& Barrasa García, S. (2013). Motivation for conservation:

Assessing integrated conservation and development projects and payments for environmental services in La Sepultura Biosphere Reserve, Chiapas, Mexico. Ecological Economics, 89(0), 92100.

Robbins, P., McSweeney, K., Chhangani, A. K., \& Rice, J. L. (2009). Conservation as it is: Illicit resource use in a wildlife reserve in India. Human Ecology, 37, 559-575.

Rode, J., Gómez-Baggethun, E., \& Krause, T. (2015). Motivation crowding by economic incentives in conservation policy: A review of the empirical evidence. Ecological Economics, 117, 270-282.

Rodríguez de Francisco, J. C., Budds, J., \& Boelens, R. (2013). Payment for environmental services and unequal resource control in Pimampiro, Ecuador. Society \& Natural Resources, 26(10),

Schaeffer, N. C., \& Presser, S. (2003). The science of asking questions. Annual review of sociology, 65-88.

Schmitt, C. (2010). Sources of civic engagement in Latin America: Empirical evidence from rural Ecuadorian communities. Journal of Development Studies, 46, 1442-1458.

Sommerville, M., Milner-Gulland, E. J., Rahajaharison, M., \& Jones, J. P. G. (2010). Impact of a community-based payment for environmental services intervention on forest use in Menabe, Madagascar. Conservation Biology, 24, 1488-1498.

Stern, P. C. (2000). Toward a coherent theory of environmentally significant behavior. Journal of Social Issues, 56(3), 407-424.

Thornberry, T. P., \& Krohn, M. D. (2000). The self-report method for measuring delinquency and crime. Criminal justice, 4, 33-83.

Tourangeau, R., \& Yan, T. (2007). Sensitive questions in surveys. Psychological Bulletin, 133, 859.

Vatn, A. (2010). An institutional analysis of payments for environmental services. Ecological Economics, $69,1245-1252$. 
Vignola, R., Koellner, T., Scholz, R. W., \& McDaniels, T. L. (2010). Decision-making by farmers regarding ecosystem services: Factors affecting soil conservation efforts in Costa Rica. Land Use Policy, 27, $1132-1142$.

Vollan, B. (2008). Socio-ecological explanations for crowding-out effects from economic field experiments in southern Africa. Ecological Economics, 67, 560-573.

Wertz-Kanounnikoff, S., \& Kongphan-Apirak, M. (2009). Emerging REDD+: a preliminary survey of demonstration and readiness activities. Bogor, Indonesia: Center for International Forestry Research (CIFOR).

Wunder, S. (2005). Payments for environmental services: Some nuts and bolts. In CIFOR Occasional Paper No. 24. Jakarta, Indonesia: CIFOR.

Wunder, S. (2013). When payments for environmental services will work for conservation. Conservation Letters, 6, 230-237.

Wunder, S., \& Alban, M. (2008). Decentralized payments for environmental services: the cases of Pimampiro and PROFAFOR in Ecuador. Ecological Economics, 65(4).

Wunder, S., Engel, S., \& Pagiola, S. (2008). Taking stock: A comparative analysis of payments for environmental services programs in developed and developing countries. Ecological Economics, 65(4), 834-852. doi:DOI 10.1016/j.ecolecon.2008.03.010 


\section{Appendix A. Household survey questions (translation from Spanish)}

1. How many people live in your house?

2. How long have you lived in the community?

3. How old are you?

4. What is your principal livelihood?

5. How many in your household contribute to your agricultural activities?

6. How many cows__ and sheep___ does your household maintain today?

7. Please take a moment to think back five years ago, when you were ( $x$ old/x events occurred), how have your agricultural (this includes grazing) practices changed. For example, have you changed the type or amount of crops you grow, your animals, where you graze your animals? (This was an open question and then a table was filled in).

8. Compared to 5 years ago (in 2008/when you were $X$ years old/when $X$ happened), does your household have: more cows today, fewer cows today, same as 5 years ago.

a. If there were changes, explain why (open question).

9. Compared to 5 years ago (in 2008/when you were $X$ years old/when $X$ happened), your household have: more sheep today, fewer sheep today, same as 5 years ago.

a. If there were changes, explain why (open question).

10. How many hectares of grazing land (individual parcels) does your household have?

11. Are there times when you have to rent pasture lands? If yes, how frequently? How much does it cost per month?

12. In the last five years, have you or anyone in your household opened new lands for pasture or agriculture? If yes, where?

13. From your house, how far is it to walk to the collective páramo lands? minutes.

14. In the past year, how often did someone from your household go to the páramo (at least once a week; a few times a month; a few times a year; never)

15. What do you consider to be the principal benefits of the páramo for your household? (open question-probed for 3).

16. In the past year, has your household used the collective páramo lands to graze cattle (for example: fighting bulls, cattle during summer/drought, etc.) (yes/no)

17. On average, how many cows does your household graze in the collective páramo lands?

18. Compared to 5 years ago (in 2008/when you were $X$ years old/when $X$ happened), your household have in the collective páramo lands: more cows today, fewer cows today, same as 5 years ago.

19. Does your household go today to the collective páramo lands for:__agriculture sheep grazing, cattle grazing medicinal plants, collect fibers, hunt, monitor lands, other (explain).

20. Compared to 5 years ago (in 2008/when you were $X$ years old/when $X$ happened), your household used the collective páramo lands: more today, fewer today, same as 5 years ago.

a. Explain (open question for each category)

b. If there were changes, explain why (open question for each category). 
21. Are there rules to restrict how your household use/extract/go today to the collective páramo lands for: __ agriculture, __ sheep grazing, cattle grazing, medicinal plants, collect fibers, hunt, ___ monitor lands, other (explain). If responded yes, was asked to explain rule.

22. How likely is that someone that does not comply with the rules will be caught? Likely, Somewhat likely Not likely.

FOR PSB PARTICIPANTS ONLY

23. Do you know, or have you heard about PSB (the government program that pays money to conserve páramo? Yes/No

24. Is your community participating in PSB? Yes/No/Don't know

25. How many years is the PSB agreement that your community signed?

26. What does the agreement say? What does the community have to do (what activities are forbidden)? (Open question). What will PSB provide?

27. In addition to the monetary incentive, are there other benefits to the community due to participation in PSB? (Open question)

28. Please indicate whether the following resulted from participation in PSB:

a. The community is more informed about conservation.

b. The rules with respect to the use of the páramo are clearer: Yes/No (explain)

c. The rules are applied more.

d. The members of the community directive are better able to meet the needs of the community. Yes/No (explain)

e. The community has gained greater support from other organizations (outside of PSB) to conserve the páramo.

29. Are there any disadvantages or costs to participating? (open question first)

30. Has participation caused any of the following:

a. The community has lost an economic resource

b. Our children will no longer have land available in the future

c. PSB now makes all the decisions on how to manage our collective páramo lands

d. There is more conflict between households

31. Considering the costs and the benefits from participation, do you think your community is better off, worse off, or the same?

32. Did your household receive any benefits due to participation (indirect benefits from communal projects and direct economic benefits)? Open question and then asked about a specific set of benefits.

33. In your household, because of participating in PSB, did you have to make changes in how you use the collective páramo lands? Yes/No (explain)

34. Due to participation in PSB:
a. Did your household have to sell animals? Yes/No (explain)
b. Did your household have to move down animals from the páramo? Yes/No (explain)
c. Buy pasture
d. Look to use another paramo 
35. Thinking in the benefits that your household has received from participating in PSB and the costs incurred, do you consider your household to be: better off, worse off, or the same?

36. Household Wealth: In this house, do you have:
a. Electricity (yes/no)
b. Flush toilet (yes/no)
c. Motorcycle (yes/no)
d. Car/truck (yes/no)
e. Cement floor (yes/no)
f. Television (yes/no)
g. Use fuelwood to cook (yes/no)
h. Piped water (yes/no) 
Appendix B.1. Community Level Characteristics. ${ }^{9}$

PSB Participant Communities $(n=6) \quad$ Non-Participant Communities $(n=5)$

\begin{tabular}{lccccccccccc} 
& Min & Max & Median & Mean & SD & Min & Max & Median & Mean & SD \\
& & & & & & & & & \\
\hline No. of households & 18 & 500 & 111 & 176 & 197 & 26 & 335 & 45 & 128 \\
Páramo size (ha.) & 419 & 3500 & 1225 & 1430 & 1077 & 564 & 2690 & 1150 & 1255 & 846 \\
Population density (households/páramo) & 0.01 & 0.72 & 0.09 & 0.21 & 0.28 & 0.01 & 0.29 & 0.06 & 0.14 & 0.14 \\
Self-organization Index & -1.358 & 1.459 & 0.47 & 0.31 & 1.02 & -0.55 & 0.71 & -0.29 & 0.03 & 0.62 \\
Monitoring and enforcement (1=yes) & 0 & 1 & 0.00 & 0.17 & 0.41 & 0 & 1 & 0.00 & 0.40 & 0.55 \\
Rule history (1=yes) & 0 & 1 & 0.50 & 0.50 & 0.54 & 0 & 1 & 1.00 & 0.60 & 0.54
\end{tabular}

\footnotetext{
${ }^{9}$ We analyzed both páramo size and community size separately, however, in the final regressions only population density is used as community size was found to be highly correlated to several other independent variables. Similarly, we analyzed monitoring and sanctioning mechanisms and perceived catch separately in the analysis and both returned similar results. In the final regressions perceived catch is used due to issues of multicollinearity. See correlation table in
} Appendix C. 
PSB Households $(\mathrm{n}=212) \quad$ Non-participant Households $(\mathrm{n}=187)$

\begin{tabular}{|c|c|c|c|c|c|c|c|c|c|c|}
\hline & Min & Max & Median & Mean & SD & Min & Max & Median & Mean & SD \\
\hline 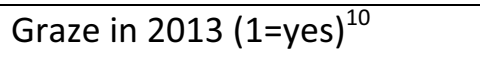 & 0 & 1 & 0 & 0.09 & 0.29 & 0 & 1 & 0 & 0.24 & 0.43 \\
\hline Graze in 2008 (1=yes) & 0 & 1 & 1 & 0.53 & 0.50 & 0 & 1 & 1 & 0.56 & 0.50 \\
\hline No. of cows & 0 & 40 & 2 & 2.83 & 3.97 & 0 & 17 & 2 & 2.63 & 2.72 \\
\hline Area pasture (ha.) $)^{11}$ & 0 & 30 & 1 & 1.90 & 3.13 & 0 & 16 & 0.71 & 1.22 & 1.79 \\
\hline Wealth Index & -2.42 & 2.54 & 0.18 & 0.12 & 1.02 & -2.42 & 2.54 & -0.09 & -0.62 & 0.99 \\
\hline Distance to páramo (minutes) & 5 & 540 & 120 & 132 & 93 & 2 & 360 & 120 & 120 & 68 \\
\hline Age & 16 & 87 & 44 & 44 & 15.5 & 15 & 84 & 42 & 44 & 15 \\
\hline Perception páramo (1=yes) & 0 & 1 & 1 & 0.63 & 0.48 & 0 & 1 & 1 & 0.54 & 0.50 \\
\hline Perceive catch ( 1 = yes) & 0 & 1 & 0 & 0.31 & 0.46 & 0 & 1 & 0 & 0.33 & 0.47 \\
\hline
\end{tabular}

\footnotetext{
${ }^{10}$ There is a statistically significant association between PSB and Graze in $2013\left(X^{2}=15.43, p=0.000, n=398\right)$, however, please note that there is no association between PSB participation and Graze in $2008\left(X^{2}=0.361, p=0.548, n=398\right)$.

${ }^{11}$ Difference in pasture owned is statistically significant $(t=-2.50, p=0.01, n=397)$ between PSB households and non-participant households. This holds when an outlier ( $30 \mathrm{ha}$ ) is excluded or when run using Mann-Whitney $\mathrm{U}$ (nonparametric test).
} 


\section{Appendix C. Correlation table}

\begin{tabular}{|c|c|c|c|c|c|c|c|c|c|c|c|c|c|}
\hline & 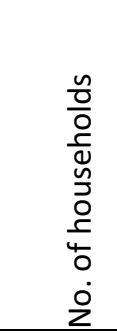 & $\begin{array}{l}0 \\
\stackrel{N}{n} \\
0 \\
\stackrel{E}{\pi} \\
\frac{\pi}{\pi} \\
0\end{array}$ & $\begin{array}{l}\frac{7}{0} \\
\text { n } \\
\frac{0}{0} \\
0 \\
0 \\
.0 \\
\frac{0}{0} \\
\frac{0}{3} \\
0 \\
0 \\
0\end{array}$ & 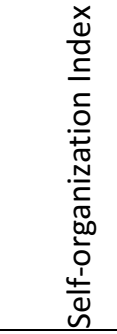 & 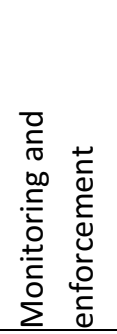 & 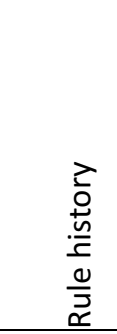 & $\begin{array}{l}n \\
3 \\
0 \\
4 \\
\text { ¿ } \\
\dot{0} \\
z\end{array}$ & 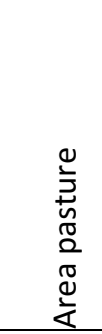 & 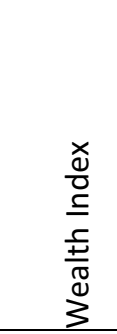 & 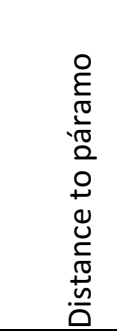 & $\stackrel{\infty}{\infty}$ & 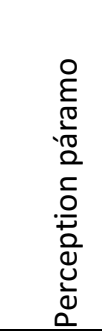 & 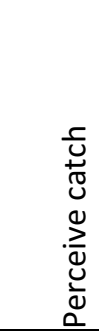 \\
\hline No. of households & 1.000 & & & & & & & & & & & & \\
\hline Páramo size & -0.269 & 1.000 & & & & & & & & & & & \\
\hline Population density & 0.708 & -0.512 & 1.000 & & & & & & & & & & \\
\hline Self-organization Index & -0.520 & -0.090 & 0.115 & 1.000 & & & & & & & & & \\
\hline Monitoring and enforcement & 0.205 & -0.156 & 0.015 & -0.385 & 1.000 & & & & & & & & \\
\hline Rule history & 0.397 & 0.483 & -0.094 & -0.732 & 0.609 & 1.000 & & & & & & & \\
\hline No. of cows & -0.112 & -0.044 & 0.048 & 0.228 & -0.125 & -0.193 & 1.000 & & & & & & \\
\hline Area pasture & -0.118 & -0.018 & 0.057 & 0.202 & -0.103 & -0.172 & 0.578 & 1.000 & & & & & \\
\hline Wealth Index & 0.138 & -0.033 & 0.164 & 0.071 & 0.076 & 0.022 & 0.206 & 0.168 & 1.000 & & & & \\
\hline Distance to páramo & -0.231 & 0.249 & -0.172 & 0.116 & -0.222 & -0.074 & 0.002 & 0.094 & -0.028 & 1.000 & & & \\
\hline Age & -0.156 & 0.079 & -0.161 & 0.035 & -0.265 & -0.150 & 0.042 & 0.099 & -0.282 & 0.166 & 1.000 & & \\
\hline Perception páramo & 0.181 & -0.218 & 0.221 & -0.038 & 0.112 & 0.016 & -0.027 & 0.023 & 0.142 & -0.109 & -0.158 & 1.000 & \\
\hline Perceive catch & 0.155 & 0.062 & 0.036 & -0.113 & 0.512 & 0.357 & -0.047 & 0.014 & 0.113 & -0.082 & -0.117 & 0.098 & 1.000 \\
\hline
\end{tabular}


Appendix D. DID communities effect.

\begin{tabular}{|c|c|c|c|}
\hline & Coeff. & Std err. & $\mathrm{t}$ \\
\hline Treat & -0.017 & 0.016 & -0.11 \\
\hline Time & -0.315 & $0.043 * * *$ & -7.21 \\
\hline PSB & 0.016 & 0.119 & 1.42 \\
\hline Treat * Community A & -0.488 & $0.191 * *$ & -2.55 \\
\hline Treat * Community B & Omitted & & \\
\hline Treat * Community C & -0.166 & 0.176 & -0.95 \\
\hline Treat * Community D & -0.115 & 0.176 & -0.65 \\
\hline Treat * Community E & 0.183 & 0.204 & 0.90 \\
\hline Treat * Community $\mathrm{F}$ & 0.068 & 0.176 & 0.39 \\
\hline Treat * Community G & Omitted & & \\
\hline Treat * Community $\mathrm{H}$ & Omitted & & \\
\hline Treat * Community I & Omitted & & \\
\hline Treat * Community J & Omitted & & \\
\hline Constant & 0.497 & $0.047 * * *$ & 10.45 \\
\hline N & & 796 & \\
\hline R-Squared & & 0.23 & \\
\hline
\end{tabular}


Note: Dependent variable is Grazing. Model includes dummy variables for each community (not shown). A few interactions were omitted due to

collinearity. ${ }^{*}, * *$, and ${ }^{* * *}$ indicates that the coefficient is significant at the $10 \%, 5 \%$ and $1 \%$ level respectively. 
